\title{
NOVI PRISTOPI PRI PROUČEVANJU PRSTI V POKRAJINI
}

\author{
Blaž Repe \\ Oddelek za geografijo, Filozofska fakulteta, Univerza v Ljubljani, Aškerčeva 2, \\ SI - I000, Ljubljana \\ e-mail: blaz.repe@ff.uni-lj.si
}

Izvirni znanstveni članek

COBISS 1.01

\section{Izvleček}

V slovenski geografiji je proučevanje prsti v pokrajini pogosto zanemarjeno kljub temu, da ima pedogeografija znotraj fizične geografije enakovredno mesto v sistemu geografskih ved. Vzroke smemo poiskati v zamudnem terenskem proučevanju, dragih laboratorijskih analizah in pedoloških podatkih ter pomanjkanju lastne metodologije. Našteto je de neke mere nadomestimo z drugačnim pristopom, $\mathrm{z}$ namenom prikaza prsti obravnavanega območja in iskanja povezav z naravnimi dejavniki. Uporaba lahko dostopnih digitalnih podatkov in kartografskega gradiva, enostavnega terenskega proučevanja, v kombinaciji s sorazmerno preprostimi GIS orodji ter kvantitativnimi metodami omogoča preskok marsikatere finančne ali časovne ovire.

Ključne besede: pedogeografija, fizična geografija, geografski in formacijski sistemi, kvantitativne metode, Bela krajina.

\section{NEW APPROACHES IN SLOVENIAN SOIL GEOGRAPHY}

\begin{abstract}
In Slovenia, soil research of a given landscape is often neglected in physical geography studies. Despite the fact of an equivalent position of soil geography within the science system of Slovene geography. Reasons can be found in time consuming field research, expensive laboratory analysis and soil data and also the lack of its own methodology. The drawbacks could be partially replaced by different approaches of research and especially to establish links with other physical elements of the environment. The use of easily accessible digital and cartographic data, basic field techniques, in combination with simple GIS tools and quantitative methods overcomes many of the financial or time constraints.
\end{abstract}

Key words: soil geography, physical geography, geographical information systems, quantitative methods, Bela krajina. 


\section{UVOD}

Ob nespornem dejstvu, da pokrajino sestavlja tudi odeja prsti, se postavlja slovenska geografija pedogeografijo enakovredno ob bok ostalim svojim vejam. Geografija prsti se je v Sloveniji začela uveljavljati v začetku druge polovice prejšnjega stoletja. V tistem času je bila zelo zaznamovana $\mathrm{z}$ dediščino pedologije in se tudi ni bistveno razlikovala od nje (Vovk Korže, 2003), kar je razvidno predvsem iz učbenikov Ilešiča (1960) in Belca (1968). Pravo pedogeografsko proučevanje sledi $\mathrm{v}$ sedemdesetih letih prejšnjega stoletja z Lovrenčakom (1970), ki obravnava prsti kot neločljivi del pokrajine ter skuša med naravnimi dejavniki poiskati vzroke za nastanek, razvoj in za prostorsko razprostranjenost prsti. Še posebej intenzivno išče povezave med prstjo in rastlinstvom. Vse do konca osemdesetih let prejšnjega stoletja je bil Lovrenčak edini, ki se je resneje ukvarjal s problematiko pedogeografije. V zadnjih dvajsetih letih se mu je pridružila tudi Vovk Koržetova s proučevanjem prstene odeje severovzhodne Slovenije (1995), vloge prsti v ekosistemu (1997) in metodologijo proučevanja prsti v pokrajini (2004). V zadnjem času spoznanja dopolnjujeta tudi Repe (2002) in Petauerjeva (2005), katerima geografija prsti prav tako predstavlja osrednje področje pedagoškega in znanstvenega udejstvovanja.

Vseeno pa nas pogled na celoten seznam del oziroma avtorjev, katerih prst je glavni predmet proučevanja, ne navdaja z navdušenjem. Prevladujeta imeni Lovrenčak in Vovk Korže in če ju odmislimo, ostane bore malo. To nas še bolj čudi, če si ponovno preberemo prvi stavek uvoda. Proučevanje prsti pogrešamo tako v celovitih fizičnogeografskih kot regionalnogeografskih raziskavah oziroma igra tam le obrobno vlogo.

$\mathrm{S}$ prispevkom ne želimo kritizirati niti preteklega niti sedanjega stanja $\mathrm{v}$ slovenski pedogeografiji ali geografiji, marveč bomo poskušali poiskati vzroke za to. Obenem bomo s predstavitvijo drugačnega pristopa in načina obravnave prsti v pokrajini naredili pedogeografsko problematiko morebiti zanimivejšo in privlačnejšo za obravnavo.

\section{POLOŽAJ PEDOGEOGRAFIJE V SLOVENSKI GEOGRAFIJI}

Slovenska geografija se s proučevanjem ali obravnavo prsti ukvarja sedaj že lepo število let. Za enega najstarejših prispevkov na to temo v slovenskem jeziku smemo šteti Erozijo prsti, objavljeno v reviji Proteus (Vrišer, 1953). Vrišer je torej očitno že leta 1953 spoznal velik pomen te sestavine pokrajine. Nedvomno se je tega zavedal tudi Ilešič $(1960 ;$ str. 1), ko je v uvodu svojih skript Geografija prsti in rastja zapisal: "Geografija tal ali prsti je eno od najvažnejših poglavij prirodne geografije. Njenega pomena ne smemo podcenjevati zato, ker je bila doslej silno zanemarjena in ker imamo celo dolgo vrsto sicer dobrih in sodobnih fizičnogeografskih knjig, ki je sploh ne vsebujejo. (...) Spričo važnosti prsti za človeka nas začudi, da spada pedogeografija med najmlajše panoge naše vede, še več, da se ponekod sploh ni rodila." Izmed visokošolskih učbenikov geografije v slovenskem jeziku, ki jih hrani knjižnica ljubljanskega Oddelka za geografijo, gre to sploh za najstarejši učbenik s področja fizične geografije. Izmed vseh ostalih sta starejša le še Gospodarska geografija sveta (1952) in Zgodovina geografije (1950) istega avtorja. Poleg pomembnosti prsti v okviru fizične geografije in za človeka, pa je Ilešič obenem opozoril na nerazvitost tega področja raziskovanja. 
Da je bilo proučevanje prsti oziroma tal takrat resnično še v povojih, nas opozarja Stritar (1965; str. 81), kot najvidnejša oseba slovenske pedologije: “Šele po vojni (2. svetovna vojna, op. p.) se je pričela razvijati veda o tleh tudi v Sloveniji. Čeprav poteka sistematično kartiranje našega prostora šele nekaj let v okviru znanstveno raziskovalnega programa Inštituta za nauk o tleh in prehrano rastlin na Biotehniški fakulteti, so na osnovi dosedanjega dela prišli pedologi do gradiva, ki nam razkriva grobe obrise tega prirodoznanstvenega področja, še posebej pa frekvenco pojavljanja posameznih talnih tipov oziroma njih zastopanost in razširjenost." Prispevek je pomemben iz več vidikov. Poleg tega, da gre za enega prvih objavljenih (delnih) pregledov slovenskih prsti, je Stritar postavil tudi temelje pedosekvenc v Sloveniji. Zanimivo pa je tudi dejstvo, da je prispevek objavljen prav v geografski publikaciji. To kaže na določeno stopnjo povezanosti med takratno geografijo in pedologijo. Čeprav Stritar v istem prispevku že oporeka geografskemu terminu "prst" in predlaga "tla" kot primernejši in ustreznejši pojem. Osnovno terminološko razhajanje ni razrešeno in poenoteno do danes (Sušin, 1983). Zdi se, da sta od tod naprej, kljub istemu predmetu proučevanja, slovenska pedologija in pedogeografija ubrali vsaka svoj pot. Pedogeografija je uporabljala izsledke pedologije, a ker so geografe zanimale druge stvari, stroki skupnega jezika nista več našli. Pedologija je prednjačila in postala standard na področju raziskovanja in kartiranja tal (prsti) Slovenije. Geografija preko svojih učiteljev edina skrbi za izobraževanje o prsteh v osnovnih in srednjih šolah.

V sedemdesetih letih se je proučevanja prsti v okviru geografije lotil Lovrenčak. Leta 1974, kot začetnik pedogeografskega proučevanja, upravičeno ugotavlja (str. 87): "Proučevanje prsti in rastja v okviru geografije je še dokaj mlado. V tuji in domači strokovni literaturi najdemo pred vojno le osamljene prispevke s tega področja." Na koncu še zaključi, da sta obe, tako pedo kot fitogeografija pri nas slabo razviti. Geografi so do takrat posvečali malo pozornosti proučevanju odeje prsti in rastja in da takratna pedogeografija pri nas in skoraj povsod drugod po svetu zaostaja za fitogeografijo. Dve leti kasneje, isti avtor bistveno ne spremeni svojega mnenja (Lovrenčak, 1976; str. 181). Opredeli predmet in položaj pedogeografije, ki je veja geografije, ki proučuje prst kot člen geografskega okolja, saj je le-ta nerazdružljivo povezana z njim. Pedogeografija še vedno velja za slabo razvito, ki se v marsičem naslanja na pedologijo, biotehniško vedo o prsteh ali tleh. Geografi zato pogosto uporabljajo metode, dognanja in izkušnje iz pedologije. Še največ pedologom dolgujemo, ko smo od njih prevzeli večji del klasifikacije prsti, ki so jo izdelali za potrebe kartiranja tal.

Vsa nadaljnja leta je ostal Lovrenčak edini, ki se je temeljiteje in poglobljeno loteval prsti kot dela pokrajine, zato nas ne preseneča, da svojih nazorov ne spremeni tudi 20 let kasneje v svojem učbeniku Pedogeografija (Lovrenčak, 1994; str. 4). Pedogeografijo ponovno opredeli kot mlado vedo, na stiku naravne geografije in pedologije. Preučevanje prsti z geografskega vidika, kot sestavnega dela pokrajine, postavi v večini geografskih šola še vedno v razvoj ali celo na sam začetek. Podoben je tudi položaj pedogeografije kot visokošolskega predmeta v okviru geografije. Marsikje je vključen kar v biogeografijo, redkeje je samostojen predmet. Posledica mladosti stroke je tudi premajhna količina visokošolskih učbenikov, tako v tujini kot pri nas ${ }^{1}$. Podrobneje Lovrenčak (1994; str 7.) opredeli tudi nastanek pedogeografije. Trditve

\footnotetext{
${ }^{1} \mathrm{Ob}$ tem je potrebno ponovno opozoriti na razliko med pedologijo in pedogeografije. S prstmi ali tlemi se ukvarja množica pedoloških učbenikov, medtem ko je pedogeografskih res malo.
} 
iz leta 1976 še konkretizira. Pedogeografija se ne le zgolj naslanja na pedologijo, pač pa se je razvila z njeno preobrazbo in iz nje nastala. To se je zgodilo, ko je uporabna pedologija, ki se ukvarja s prstmi kot rastiščem za kulturne rastline, prešla $v$ genetsko pedologijo, ki smatra prst kot naravno telo, nastalo v pedogenetskih procesih. Lovrenčak tako pojasni temelje slovenske pedogeografije in njen izrazit genetski pristop, ki ga zagovarja tudi sam.

O razvoju geografije prsti je spregovorila tudi Vovk Koržetova (2003a; str. 92-93). Ugotavlja zamujanje širjenja znanja o prsteh znotraj geografije. Za takšno stanje krivi sámo fizično geografijo, ki (pre)dolgo časa ne uspe razviti samostojnih metod proučevanja. Vovk Koržetova kritizira preveč izrazito navezanost na dediščino pedologije, kar se je odražalo tudi v geografskih študijskih gradivih do leta 1975. Nič manj pa ni kritičen njen pogled na današnje stanje v geografiji in na položaj pedogeografije znotraj nje (Vovk Korže, 2003a; str. 97). Pridobljeno znanje o prsteh na stopnji tako pedagoške kot nepedagoške geografije je zelo splošno, ne znamo ga povezati v smiselno celoto ali poiskati povezave, kaj šele, da bi znanje uporabili v praksi. Geografi se tudi mnogo premalo vključujemo v sorodne raziskave in ne sodelujemo s pedologi. Zaključek je sicer bolj optimističen, saj pedogeografske vsebine in metodologija nakazujejo sodobne trende proučevanja.

Smemo po vsem navedenem in naštetem danes vendarle zapisati, da pedogeografije ne štejemo več mlada področja geografskega proučevanja v Sloveniji? Odgovor žal ni enoznačen in zanj ne moremo podati preprostih razlogov.

$\mathrm{Z}$ določenega zornega kota lahko prejšnjemu vprašanju z veseljem pritrdimo. Preko pol stoletja strokovno-znanstvenega, raziskovalnega in pedagoškega udejstvovanja vsekakor ni malo. Poleg tega imamo v slovenskem jeziku kar tri visokošolske pedogeografske učbenike (Ilešič, 1960; Belec, 1986; Lovrenčak, 1994), s čimer se ne morejo pohvaliti niti slovenski pedologi. Slovenska geografija prsti ima tudi tri metodološke priročnike. Dva, ki dajeta podrobne, a lahko razumljive napotke za delo v fizičnogeografskem laboratoriju (Lovrenčak, 1979; Vovk Korže in Lovrenčak, 2001) in kako iz vzorcev prsti izluščiti tiste informacije, ki jih lahko uporabimo pri razlagi stanja in procesov v pokrajini. Pred dvema letoma pa sta Vovk Koržetova in Lovrenčak (2004) objavila še smernice za kar najbolj učinkovito terensko proučevanje. Osnovnošolski in srednješolski učni načrti za geografijo skrbijo, da prsti spoznajo tudi tisti, ki študija ne bodo nadaljevali na geografiji, agronomiji, gozdarstvu, krajinski arhitekturi ipd. Še več. Ker skuša geografija učencem in dijakom prikazati razprostranjenost prsti tudi drugod po svetu, ne le v Sloveniji, je na visokošolskem nivoju posebna skrb posvečena tudi klasifikacijam in tipom prsti izven naših meja. Geografi edini v Sloveniji objavljamo prispevke o prsteh vsega kopnega na Zemlji (Lovrenčak, 1976; Lovrenčak, 1994; Vovk Korže, 2003c; Vovk Korže in Lovrenčak, 2004; Repe, 2005a; Repe, 2005b; Repe, 2006) in prav na tem področju je čutiti velik primanjkljaj sodelovanja s slovensko pedologijo, saj so terminološke zadrege velike in njih reševanja ne smemo prepustiti zgolj eni stroki. Če k temu vsemu pridamo še raziskovalno dejavnost ter strokovne članke in znanstvene prispevke, se je količina znanja v pedogeografiji obogatila do te mere, da je nikakor ne moremo postaviti na sam začetek razvoja.

Drugo plat medalje nam razkrije že zelo enostavna analiza zapisov v slovenskem jeziku ${ }^{2}$ na spletni strani vzajemne bibliografsko-kataložne baze podatkov COBIB.SI (COBISS/OPAC V4.2) ${ }^{3}$. Iskanje po ključnih besedah posameznih vej fizične geografije in nekaterih njihovih 
sorodnih strok pokaže, da je število prispevkov, v katerih se pojavljajo prsti kot osrednja ali vsaj obrobna tema najmanjše med vsemi (preglednica 1). Število takšnih prispevkov je primerljivo s števili zapisov sorodnih ved. Tudi letnica najstarejšega prispevka v knjižnici ljubljanskega oddelka za geografija je pri pedogeografiji najmlajša med vsemi vejami fizične geografije. Pri sorodnih pa je edino pedološki(!) prispevek še mlajši.

Preglednica 1: Število zapisov po ključnih besedah geografskih vej in sorodnih strok v spletni bazi v slovenskem jeziku

Table 1: Number of works (records) in Slovene language in COBISS according to differenet branches of geography

\begin{tabular}{|l|r|r|r|r|}
\hline \multirow{2}{*}{ ključna beseda } & \multicolumn{2}{|c|}{ število zapisov v COBISS $^{*}$} & \multicolumn{2}{c|}{$\begin{array}{c}\text { leto zapisa v COBISS knjižnice } \\
\text { Oddelka za geografijo }\end{array}$} \\
\cline { 2 - 5 } & celotna baza & $\begin{array}{r}\text { knjižnica Oddelka } \\
\text { za geografijo }\end{array}$ & najstarejši & najmlajši \\
\hline fizična geografija & 1303 & 1418 & 1874 & 2006 \\
\hline geomorfologija & 781 & 583 & 1924 & 2006 \\
\hline klimatogeografija & 180 & 285 & 1929 & 2006 \\
\hline hidrogeografija & 241 & 321 & 1898 & 2005 \\
\hline pedogeografija & $\mathbf{1 3 3}$ & $\mathbf{1 2 9}$ & $\mathbf{1 9 5 3}$ & $\mathbf{2 0 0 5}$ \\
\hline biogeografija & 86 & 174 & 1912 & 2006 \\
\hline geologija & 4125 & 262 & 1907 & 2005 \\
\hline klimatologija & 307 & 32 & 1947 & 2005 \\
\hline meteorologija & 888 & 97 & 1929 & 2005 \\
\hline hidrologija & 864 & 71 & 1951 & 2005 \\
\hline pedologija & 863 & 19 & 1954 & 2005 \\
\hline botanika & 1978 & 41 & 1969 & 2005 \\
\hline fitocenologija & 167 & 10 & 1974 & 2004 \\
\hline
\end{tabular}

" ponekod je število zapisov na knjižnici Oddelka za geografijo večje kot v celotni bazi. Razlika je pri tistih delih, ki jih kot prve vnesejo na drugih knjižnicah in ne vpišejo predmetne oznake npr. biogeografija. Ko omenjeno oznako doda geografska knjižnica, lahko delo s to predmetno oznako zabeleži le iskanje neposredno na oddelku, v celotni bazi pa se nam ne izpiše.

Vir: COBISS/OPAC V4.2, 11.3.2006

Seveda so te absolutne vrednosti med seboj težje primerljive, ker nanje močno vpliva tudi število avtorjev (geografov), ki so se ukvarjali s posamezno tematiko. Po drugi stran pa

\footnotetext{
${ }^{2}$ Iskalni pogoji so bili omejeni na zapise, katerih jezik je bil označen kot slovenski, s čimer smo izločili vso tujo literaturo in vire. Zavedamo se, da smo tako katerega od prispevkov izpustili ali napačno uvrstili. Prikazane vrednosti zato po vsej verjetnosti niso povsem točne, a vseeno dovolj dobro prikazujejo razmerja prispevkov med posameznimi vejami oziroma strokami.

${ }^{3}$ Iskanje in analiza zadetkov sta bili opravljeni na dan 11.3.2006.
} 
pregled avtorjev (ob tem nismo upoštevali pedologov in ostalih negeografov), ki so prispevali več kot eno delo s ključno besedo navedeno pedogeografija, razkrije, da se (je) resnično malo slovenskih geografov ukvarja(10) s proučevanjem prsti v pokrajini:

Preglednica 2: Avtorji in število njihovih del, ki imajo kot ključno besedo navedeno pedogeografijo in so napisani $v$ slovenskem jeziku

Table 2: Authors and the number of their work in Slovene language in COBISS that can be found by a "Soil geography" keyword

\begin{tabular}{|l|c|}
\hline avtor $^{4}$ & $\begin{array}{c}\text { število del s ključno } \\
\text { besedo pedogeografija }\end{array}$ \\
\hline Lovrenčak Franc & 59 \\
\hline Vovk Korže Ana & 27 \\
\hline Repe Blaž & 8 \\
\hline Radinja Darko & 2 \\
\hline Komac Blaž in Zorn Matija & 2 \\
\hline Petauer Milena & 2 \\
\hline
\end{tabular}

Vir: COBISS/OPAC V4.2, 11.3.2006

Tudi študentje se redko odločajo za proučevanje prsti. Na ljubljanskem Oddelku za geografijo je bilo izdelanih sicer sorazmerno veliko seminarskih nalog. S ključno besedo pedogeografija jih je 123, od tega 50 z območja Slovenije (Spletni katalog..., 2006). Kot mentor se pojavlja edino Lovrenčak, z izjemo dveh nalog, katerima mentor je bil z eno regionalno in eno hidrogeografsko Dušan Plut. Veliko število seminarskih nalog pa ni merodajno, ker je letna količina izdelanih nalog s področja pedogeografije predpisana in obvezna. Odvisna je od števila vpisanih $\mathrm{v}$ drugi oziroma tretji letnik študija in se giblje od 10 do $15 \mathrm{v}$ posameznem letniku. Veliko boljši pokazatelj nezanimanja za pedogeografijo so diplomska dela. Tista, ki vsebujejo ključno besedo pedogeografija je vsega skupaj le 11 (Radišek Kuhar, 1992; Ramšak, 1993; Ferder, 1994; Pekolj, 1994; Petrevčič, 1994; Slapernik, 1994; Podgoršek-Golob, 1995; Klemen, 1996; Žvan-Hrvatin, 1996; Merzlak, 1998; Uršič, 2001). Prav vsem pa je bil mentor Lovrenčak. Vse naloge so s področja regionalne geografije in prsti predstavljajo le določen vsebinski del. Zelo verjetno so se teme prsti dotaknile tudi druga diplomska dela, a tako obrobno, da si ključne besede pedogeografija niso prislužila.

Vovk Koržetova (2003b; str. 98) ugotavlja, da gre za splošen upad zanimanja za fizičnogeografsko proučevanje, saj naj bi bilo med letoma 2000 in 2002 od skupnega števila diplomskih del takšnih le dobrih $10 \%$. Tudi v pregledu objav znanstvenih in strokovnih del geografov je čistih fizičnogeografskih prispevkov zelo malo, saj se večinoma vsebinsko navezujejo na okoljevarstveno problematiko (ekologizacija fizične geografije).

\footnotetext{
${ }^{4}$ Pri prispevkih Radinje (aluvialne naplavine; 1967, 1969) predstavljajo prsti manj pomemben oziroma le obroben del širše raziskave.
} 
Poleg splošnega trenda, gre za majhno število diplomskih del vsekakor kriviti tudi študijski program ljubljanskega Oddelka. V višjih letnikih trenutno ne ponuja dovolj možnosti poglabljanja vsebin iz fizične geografije, usmeritev geografije krasa in varstva okolja pa očitno ne zadostujeta.

Je torej pedogeografija še vedno mlada veja geografije?

Dokaj pozen začetek ukvarjanja s prstmi tako $\mathrm{v}$ pedologiji kot pedogeografiji, predvsem primerjalno z ostalimi vejami in strokami, uvršča to področje med mlajše. Ostala raziskovalna področja bodo tako vedno imela vsaj nekaj desetletij naskoka. Bolj kot teh nekaj let je zaskrbljujoče, da se ne zmanjšuje relativna razlika, predvsem zaradi majhnega števila raziskovalcev in posledično manjšega števila objavljenih del. Obenem pa je peščica opravila ogromno dela v zelo kratkem času. Pedogeografija je lahko zgled marsikateri stroki predvsem na izobraževalnem in metodološkem področju.

Pedogeografija v Sloveniji, kot veja fizične geografije vsekakor ni več na samem začetku svojega razvoja. Predvsem Lovrenčak se je uspešno spopadel z vsemi začetnimi težavami in jih tudi prebrodil. Na srečo so se mu v zadnjih letih pridružili še drugi, ki pa bodo morali postoriti še veliko dela za napredek in razvoj proučevanja prsti, kot neločljive sestavine pokrajine. Intenzivnejše in bolj poglobljeno delo na dodiplomskem študiju bo prineslo tudi večje zanimanje za prsti znotraj celotne geografske stroke. In ob tem se smemo nadejati tudi interesa pri podiplomskih študentih. Še več dela nas čaka na področju s prstjo povezane terminologije, ki je resnično še v povojih in skupaj s pedologijo močno zaostajamo za ostalim svetom. Ogromna praznina zeva na področju kartografskih prikazov razprostranjenosti prsti v pokrajini. Tematske karte spadajo med najbolj osnovne načine geografovega proučevanja pokrajine ter zasedajo prvo mesto med oblikami prikazov rezultatov geografskega proučevanja.

\section{PROUČEVANJE PRSTI V POKRAJINI}

Temelj geografovega dela je vsekakor terensko delo. Proučevanje prsti pri tem ni izjema. Zbiranje podatkov in informacij o pokrajini, neposredno v sami pokrajini je osnovni pogoj za uspešno geografsko raziskovalno delo. S terenskimi metodami proučevanja prsti se seznanijo učenci že v osnovni in srednji šoli. Terenske metode kasneje nadgradijo študentje geografije, s čimer si ustvarijo še popolnejšo sliko o prsteh v pokrajini (Vovk Korže in Lovrenčak, 2004). Sam postopek raziskovanja se začne s pripravo na terensko delo, v kabinetu. S pregledom literature, kartografskih, slikovnih in podatkovnih virov za izbrano območje si ustvarimo pravilno podobo o pokrajini, predvsem pa racionaliziramo terensko delo. Resno raziskovalno delo v pedogeografije si tudi zelo težko predstavljamo brez uporabe laboratorija. Vzorci, ki jih naberemo iz izkopanih profilnih jam oziroma sveže razkritih profilov, potrebujejo kvantitativno določitev mehanskih in kemijskih lastnosti. Same lastnosti kot take geografom še zdaleč ne zadoščajo. Z njihovo pomočjo razložimo elemente pokrajine in procese, ki so vplivali na nastanek, razvoj, lastnosti, razporeditev ter položaj prsti v pokrajini. V zaključek bi moralo biti bistvo geografskega proučevanja; prikaz razporeditve prsti v pokrajini in ugotovitev povezav s pokrajinskimi dejavniki, pogosto predvsem naravnimi (slika 1). 
Predstavljen način proučevanja prsti $\mathrm{v}$ geografiji ne prinaša prav nič novega ali revolucionarnega. Spoznal ga je vsak, ki se je vsaj dotaknil geografskega raziskovanja. Ko proučujemo prsti, pa so zadeve le nekoliko drugačne, pogosto kar zapletene.

Slika 1: Proučevanje prsti v pokrajini

Picture 1: Landscape soil research

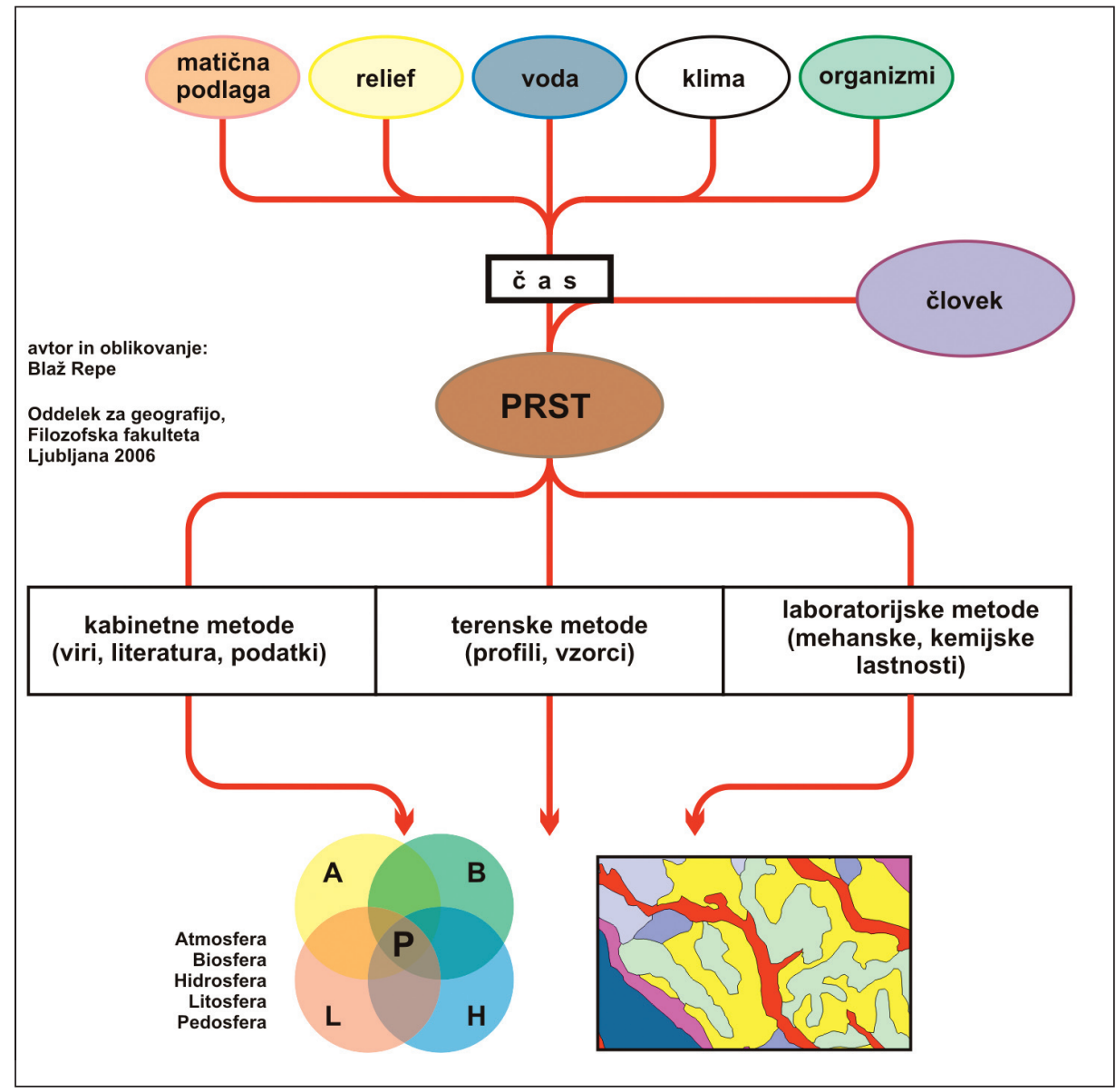

\section{I. Kabinetne metode proučevanja prsti}

$\mathrm{Na}$ sami začetni stopnji proučevanja nam morajo biti povsem jasni cilji in namen proučevanja. Kaj želimo doseči z raziskavo, nas vodi v izbor ustrezne literature in virov, iskanja reprezentativnih lokacij na terenu, na katerih bodo informacije o proučeni prsti omogočale učinkovite zaključke. Sledi seznanitev s samo pokrajino. Da bomo tipe prsti, njihove lastnosti 
in razporeditev kasneje zmogli razumeti in razložiti, moramo dobro poznati pedogenetske dejavnike in iz njih sklepati na pedogenetske procese. Zbiranje geološkega, vegetacijskega in ostalega tematskega kartografskega gradiva, analiza meteoroloških in hidroloških podatkov, prebiranje elaboratov, monografij, komentarjev kart ter ostalega gradiva, ki se nanaša na proučevano območje, je temelj za dobro delo in orientacijo na terenu. Ob tem lahko marsikaj povedo tudi letalski posnetki, ali še bolje različne digitalne baze podatkov kot so digitalni ortofoto posnetki, satelitski, radarski posnetki itd.

Zbiranje ter urejanje literature, gradiva in podatkov je lahko zelo dolgotrajno opravilo (Vovk Korže, 2003a). Viri so zelo raztreseni, tisti ki so zbrani, so pregledni in premalo natančni ali konkretni. Časovno zahtevno opravilo pa ni vedno upravičeno, kar je zelo opazno na dodiplomskem študiju. Vse preveč časa se nameni nekritičnemu zbiranju gradiva. Kopičenje informacij jemlje veliko časa, pogosto tudi denarja. Na koncu kopica gradiva prej škodi kot koristi, saj ne znamo izluščiti pravih oziroma koristnih informacij in za konkretno delo zmanjka časa. Podobno past nastavljajo tudi spletne strani. Vse je na voljo in le "klik" na povezavo stran od nas. Prispevki na obravnavano tematiko ali proučevano območje so napisani v poljudnem, zelo vabljivem in lahko razumljivem jeziku. Obilica grafičnega in slikovnega materiala kar kliče po uporabi. Žal predvsem študenti ne znajo ločiti znanstvenih od poljudnih prispevkov ter pravih informacij od senzacionalistično naravnanih puhlic.

Posebno poglavje kabinetnega proučevanja prsti je zbiranje pedološkega gradiva. Naše delo bo znatno olajšano če je dostopna regionalna pedološka (pedogeografska?) literatura, tematske karte, rezultati analiz prsti, elaborati kmetijskih služb ali gozdnih gospodarstev. Iskanje povezav s pedogenetskimi dejavniki lahko delno opravimo še preden se odpravimo na teren, kjer nato zaključke in zveze potrjujemo, spreminjamo, zavračamo ali usklajujemo z dejanskim stanjem. Pedološkega gradiva pa je, glede na opravljeno delo kolegov pedologov, dostopnega sorazmerno malo. Tiskane pedološke karte 1:50.000 s komentarji so objavljene le za tri območja (Stepančič s sod., 1986) Slovenije (Ljubljana, Ptuj, Murska Sobota), pedološke karte 1:25.000 pa so dostopne le pod zelo omejenimi pogoji(izposoja ni mogoča!)na Biotehniški fakulteti. Pedološke karte posedujejo tudi nekateri sedeži upravnih enot (občinskih, kmetijskih, gozdnogospodarskih itd.). Kartografsko gradivo ni vedno na voljo za raziskovalno dejavnost, pogosto je v rokopisni obliki in z nepopolnimi legendami. Ogromen korak naprej predstavlja digitalna pedološka karta Slovenije 1:25.000. Zelo natančno opredeljene, vektorsko zasnovane prostorske enote in njihove atributivne baze podatkov ter opisani profili prsti so neprecenljiv vir informacij o pokrajini (slika 2). Poleg tega so neposredno povezljivi z GIS orodji in takoj pripravljeni za nadaljnje analize (Digitalna..., 2005). Žal so tudi za strokovno-raziskovalne ali pedagoške namene podatki na voljo le po komercialnih cenah, ki si jih posameznik nikakor ne more privoščiti že za malenkostno večje proučevano območje. Da se stvari vendarle obračajo na bolje, kažejo rezultati projekta URBSOIL (2005), ki so v celoti in popolnoma brezplačno na voljo na spletnih straneh. 
Slika 2: Izrez iz digitalne pedološke karte Slovenije 1:25.000 z mednarodnim FAO WRB poimenovanjem in primer podatkov o pedološkem profilu

Picture 2: Part of the digital soil map of Slovenia 1:25.000 with FAO WRB units and profile descriptions

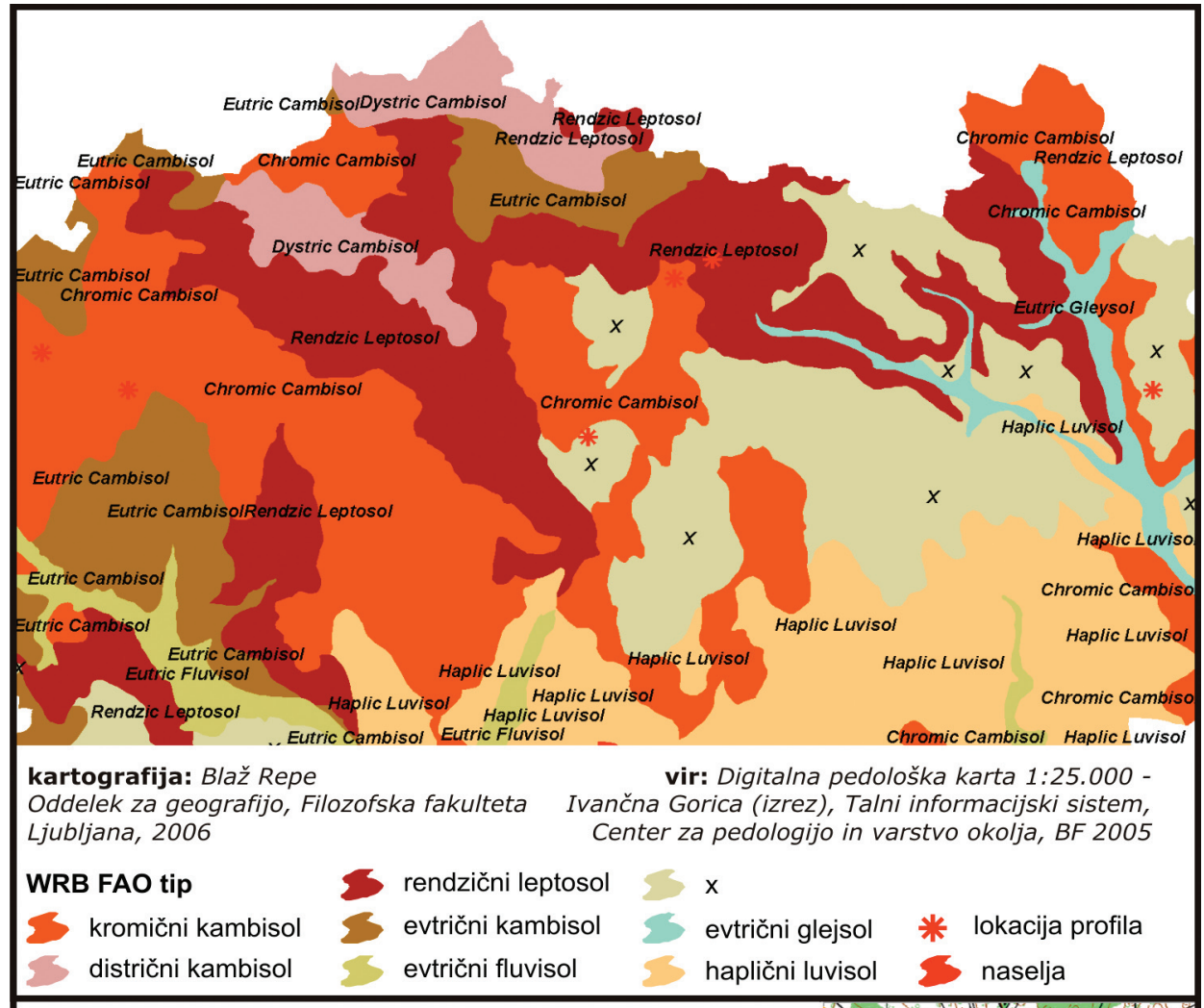

Zap. št. profila: 1132 Št. v projektu:14D

Kraj: VIŠNJE

TK 1:25000:ŽVIRČE - $155(030-2-3)$

GK: $X=487500 \mathrm{~m} \quad Y=73300 \mathrm{~m}$

Naklon: $8 \% \quad$ Ekspozicija: JUG

Relief: GRIČEVNAT

Raba tal: REDEK GOZD S KOŠENI. (HRAST, LESKA)

Tip tal: RENDZINA, NA APNENCU,SPRSTENINASTA

PKE: 1536 (RJ.POKARB./apn.+dol.tip.pl.70\%, RENDZINA,/apn.SPRSTENINASTA SKALOVITA pl.30\%)

Matična podlaga: APNENEC $\quad(15-20 \mathrm{CM}+$, APNENEC $)$

Leto izkopa profila: 96 Horizonti v profilu: A11-A12-C

A11 (0-6cm) A12 $(6-20 \mathrm{~cm})$

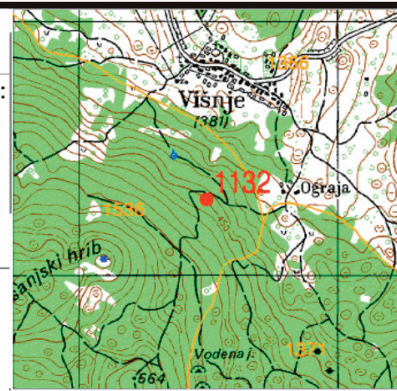

\begin{tabular}{|c|c|c|c|c|c|c|c|c|c|c|c|c|c|c|c|c|}
\hline $\begin{array}{l}\text { LAB. } \\
\text { ŠT. }\end{array}$ & HORIZONT & $\begin{array}{l}-\mathrm{pH} \\
\mathrm{H}_{2} \mathrm{O}\end{array}$ & $\begin{array}{l}\text { redn } \\
\mathrm{KCl}\end{array}$ & $\begin{array}{l}\text { ost- } \\
\text { acet }\end{array}$ & $\underset{\%}{\text { PESEK }}$ & $\begin{array}{c}\text { grobi } \\
\text { MELJ } \\
\%\end{array}$ & $\begin{array}{c}\text { fini } \\
\text { MELJ } \\
\%\end{array}$ & $\begin{array}{c}\text { skupn } \\
\text { MELJ } \\
\%\end{array}$ & i $\underset{\%}{\text { GLINA }}$ & $\begin{array}{l}\text { TEKST. } \\
\text { razred }\end{array}$ & $\begin{array}{r}\mathbf{P}_{2} \mathbf{O}_{5} \\
--\mathrm{mg} /\end{array}$ & $\begin{array}{r}\mathbf{K}_{2} \mathbf{O} \\
100 \mathrm{~g}\end{array}$ & $\begin{array}{r}\text { OS } \\
\%\end{array}$ & $\begin{array}{l}\text { C } \\
\%\end{array}$ & $\begin{array}{l}\mathbf{N} \\
\%\end{array}$ & $\mathrm{C} / \mathrm{N}$ \\
\hline 53 & $\mathrm{~A} 11$ & 6,9 & 6,1 & 7,2 & 15,0 & 50,8 & & 50,8 & 34,2 & $M G$ & 0,3 & 10,1 & 8,8 & 5,1 & 0,44 & 11,6 \\
\hline 54 & $\mathrm{~A} 12$ & 7,4 & 6,4 & 5,8 & 14,0 & 45,4 & & 45,4 & 40,6 & MG & 0,1 & 4,3 & 4,2 & 2,4 & 0,26 & 9,4 \\
\hline
\end{tabular}


Zbiranje gradiva z namenom proučevanja prsti je vse prej kot lahko delo. Pogosto se soočimo $\mathrm{z}$ nepremostljivimi težavami in praktično nedostopnostjo podatkov. V prvi vrsti manjka poglobljena, pregledna in objavljena slovenska, regionalna, pedološka študija, z vsem pripadajočim kartografskim gradivom.

Kljub začetni kritiki, da je kabinetna faza časovno izredno potratna, smo mnenja, da se ji posveti premalo pozornosti (in časa). Manjka predvsem kritičen pretres pridobljenih virov in začetna sinteza (delovna hipoteza), ki nas vodi, usmerja in omogoča vrednotenje vseh novih informacij. Marsikdaj so zato kasneje trudoma pridobljena terenska in draga laboratorijska spoznanja brez prave vrednosti in neuporabna.

\subsection{Terenske metode proučevanja prsti}

Posebna pozornosti pri proučevanju prsti v pokrajini je namenjena terenskemu delu. Neposredno v pokrajini preverjamo delovne hipoteze, ki smo si jih postavili v "kabinetu", o povezavah med pokrajinotvornimi dejavniki in procesi ter prstmi (Vovk Korže in Lovrenčak, 2004). Na terenu vzamemo tudi vzorce prsti za laboratorijske analize, katerih rezultati nam bodo potrdili, ovrgli ali dopolnili naše hipoteze, razkrili marsikatero skrito povezavo, ki je očem nevidna in nas popeljali do novih spoznanj o prsteh, njihovi razprostranjenosti in o pokrajini sami.

Še pred odhodom na teren smo morali sprejeti odločitev, ali bo naše proučevanje temeljilo zgolj na terenskem proučevanju, ali bomo tudi jemali vzorce za nadaljnje analize v laboratoriju. Metodam in postopkom, ki jih uporabljamo pri proučevanju prsti na terenu, namreč zelo težko pripišemo izvor, ne glede na to ali so jih odkrili v pedologiji ali pedogeografiji oziroma se v eni ali drugi stroki pogosteje uporabljajo. Resnično je, da so nekatere metode zelo splošne in spoznavne, druge zelo ozko fizikalno ali kemijsko specializirane. Pa vendar je njihova razlaga in teoretična podlaga vsake stroke tista, kar naredi podatke uporabne. Zopet sta cilj in namen proučevanja tista, ki narekujeta katere metode bomo izbrali.

Spoznanja, ki smo jih pridobili s pomočjo virov in literature, moramo na terenu kar se da koristno uporabiti. Kabinetni zaključki, v kombinaciji s teoretično pedogeografsko podlago in izkušnjami s terenskim proučevanjem nam pomagajo izoblikovati podobo o prsteh v pokrajini. Ob prvem prehodu ali pregledu proučevanega območja vršimo pregled geološke zgradbe, makro in mikro reliefnih potez, pokrova vegetacije, ostalih naravnih in družbenih dejavnikov ter obenem zbiramo prve informacije o zastopanosti in razprostranjenosti glavnih tipov prsti. Poleg tega si zabeležimo tudi vse naravne in umetne useke, kjer so odgrnjeni ali odprti profili prsti. Najpogosteje gre za lokacije ob cestah, kamnolomih in peskokopih, gradbiščih, tam kjer se vršijo različna zemeljska dela (kopanje infrastrukturnih kanalov in jarkov ter temeljev za hiše, postavljanje električnih in telefonskih stebrov), uporabimo pa lahko tudi erozijske jarke. Če na našem območju takih usekov ni, bo potrebno kopati plitvejše ali globlje profilne jame oziroma vrtati sondažne vrtine. Pri pregledu terena, odvisno od namena kartiranja, beležimo rabo tal nivo gladino tale vode, kmetijske pridelke itd. (Metodika..., 1967). Vse našteto preverjamo, da določimo mesta, kjer bomo prsti konkretno proučevali. 
Izbor vzorčnih mest oziroma načrt vzorčenja je odvisen od namena proučevanja in ga $\mathrm{v}$ glavnem razdelimo v dve skupini (Metodika..., 1967; Bridges in Davidson, 1982; Soil Survey Division Staff, 1993; McCoy, 2005):

- prost ali eksperten načrt vzorčenje ter

- sistematičen načrt vzorčenje.

V geografiji najpogosteje želimo pridobiti pregledne informacije o prsteh v pokrajini. V takšnem primeru je najprimernejši in časovno ter finančno najbolj ugoden prost ali eksperten načrt (slika 3) vzorčenja. Ko hodimo po terenu, opazujemo in beležimo svoja opazovanja o prsteh na podlagi znanja, ki smo ga pridobili iz virov in literature, interpretacije same pokrajine in lastnega (ekspertnega) znanja. V mislih ali na karti določamo navidezne razmejitvene črte med tipi prsti na podlagi sprememb reliefa (oblike, naklon, ekspozicije...), vodnih razmer in vegetacije. V kulturni pokrajini se je mogoče zelo dobro orientirati tudi po vzorcu rabe tal. Izdelamo načrti vzorčenja z lokacijami izkopov pedoloških jam ali vrtin s svedrom. $\mathrm{V}$ primeru zadostnega teoretičnega znanja o prsteh ter praktičnega poznavanja pokrajine je takšno vzorčenje prsti zelo učinkovito in relativno hitro. Glede na to, da skušamo iskati edinstvene kombinacije naravnih dejavnikov, se izognemo "nepotrebnim" in podvojenim vzorcem v enolični pokrajini, saj prosto izbiramo gostoto meritev. Uporaba prostega vzorčenja zahteva dobro kartografsko podlago, tako splošno kot tematsko in široko paleto dodatne literature ter veliko znanja in izkušenj. Dodatna slabost je tudi vedno prisotna pristranskost, česar posledica je, da vzorčenje ni naključno. Zaradi nenaključnosti je uporaba nekaterih statističnih analiz precej omejena. Kljub tej izraziti pomanjkljivosti je prosto vzorčenje med najbolj uporabljenimi in še posebej primerno $\mathrm{v}$ geografskem proučevanju prsti. $\mathrm{V}$ to skupino izbora vzorčnih mest spada tudi vzorčenje po naročilu, kjer nam naročnik raziskave natančno določi lokacije ali kombinacijo dejavnikov, ki vplivajo na lastnosti prsti (na primer ob izvoru onesnaženja, v izbranem vinogradu itd.).

Da zadostimo pogojem precejšnjega števila nadaljnjih statističnih obdelav, moramo zagotoviti, da ima vsaka točka $v$ pokrajini enako verjetnost, da je izbrana kot vzorčno mesto. $\mathrm{V}$ tem primeru uporabimo sistematičen izbor vzorčnih mest. Sistematičen načrt vzorčenja uporabljamo v pokrajini, kjer je razglednost omejena oziroma je pokrita z gosto, gozdno vegetacijo. V takšnih pogojih je ugotavljanje lokacij za prosto vzorčenje težavno, reliefne poteze so zabrisane, zato zelo težko določamo navidezne razmejitvene črt med tipi prsti. Sistematično vzorčenje uporabljamo tudi takrat, ko je relief blag in neizrazit, obenem pa niso razvidne geološke poteze in razlike v vegetaciji. Proučevanje prsti na podlagi lokacijsko neodvisnih meritev izloča subjektivni element interpretacije, obenem omogoča ponovitve $\mathrm{v}$ kasnejših obdobjih, od vzorčevalca pa hkrati ne zahteva teoretičnega predznanja, izkušenj in spretnosti. Velika slabost te metode je njena neprilagodljivost na območjih, kjer je vzorec razporeditve prsti enostaven in zato vodi v nepotrebno izgubo časa in truda. Problematične so tudi lokacije, ki sovpadajo s prometnicami, pozidanimi ali vodnimi površinami, kjer vzorcev ne moremo vzeti. Večjo kvaliteto vzorčenja dosežemo z večjo gostoto mreže, s čimer skokovito narašča število vzorcev, porabljen čas in denar. Znotraj sistematičnega vzorčenja obstaja več podvrst načrtov (slika 3 ). 
Ne glede na izbran vzorčni načrt je nujno, da ob vsaki lokaciji zabeležimo kar največ parametrov in podrobnosti, kijih je mogoče zbrati. Vrednost takšnih informacij je neprecenljiva, še posebno, če so potrebne kasnejše ali dodatne interpretacije oziroma ponovitve - monitoring (Zupan, 2002; Urbsoil, 2005). Zavedati se moramo tudi, da nekatere meritve in opazovanja lahko opravimo le neposredno na terenu in jih z laboratorijskimi analizami ni mogoče nadomestiti:

- $\quad$ opis lokacije, kjer se nahaja profil,

- globina/debelina profila in horizontov,

- opis profila in horizontov,

- barva naravnega vzorce,

- ocena biološke aktivnosti (rovi deževnikov in manjših sesalcev),

- ocena prekoreninjenosti,

- temperatura prsti in

- fotografiranje profila prsti.

Slika 3: Načini izbora vzorčnih mest za proučevanje prsti

Picture 3: Setting of soil sampling pattern

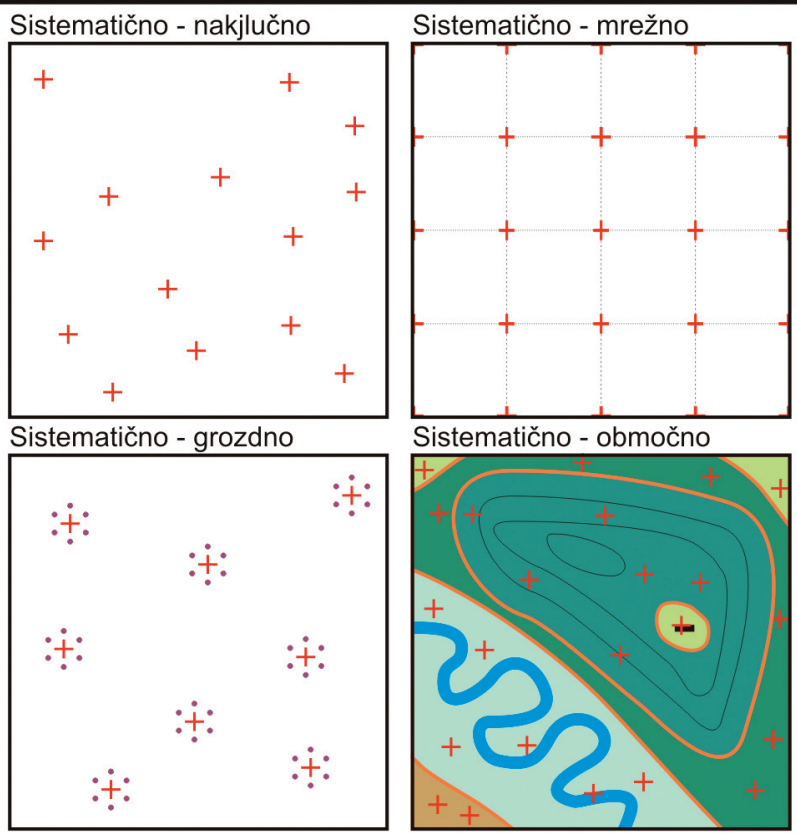

vir: Bridges in Davidson, 1982; McCoy, 2005

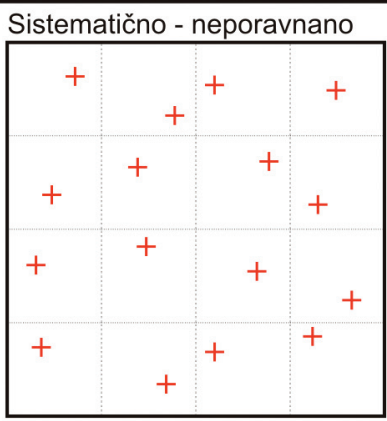

Prosto (ekspertno)

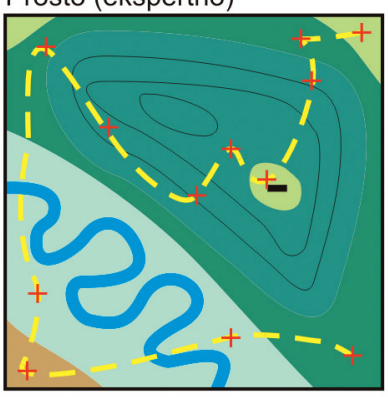

avtor in oblikovanje: Blaž Repe Oddelek za geografijo, Filozofska fakulteta, 
Na v naprej ali sproti izbranih lokacijah nato proučimo lastnosti prsti. Proučevanje lastnosti na terenu in jemanje vzorcev zahteva terensko opremo in pripomočke. Kartografsko gradivo (splošno in tematsko), ključi za določevanje rastlin, kompas, višinomer in naklonomer nam olajšajo orientacijo na terenu, prepoznavanje in beleženje lokacij proučevanja ter njihovih osnovnih značilnosti (naklon, ekspozicija, nadmorska višina, reliefna oblika, matična podlaga, prevladujoča vegetacijska oblika). Ostali pripomočki, kot tudi njihova uporaba in postopki proučevanja prsti na terenu, so odvisni od namena proučevanja in so podrobneje in odlično navedeni v dostopni (Soil Survey Division Staff, 1993), celo geografski literatura (Naša..., 1982, Vovk Korže in Lovrenčak, 2001 in 2004).

Terensko proučevanje prsti je zahtevno opravilo. Učinkovito delo zahteva precej teoretičnega predznanja in terenskih izkušenj. Obenem je delo tudi fizično precej naporno, še posebej, če se odločimo za proučevanje na podlagi profila prsti in kopanjem pedološke jame. Terensko delo $\mathrm{v}$ pedogeografiji je tudi časovno zamudno in zahteva lepo vreme. Izkušnje pokažejo, da je študentom in dijakom, kljub naporom in umazaniji, terensko delo všeč, vendar se ga kasneje ob pisanju diplomskih del ali kot učitelji v šolah izogibajo. Pri znanstvenem in strokovnem proučevanju, pa terensko delo vse bolj pridobiva na veljavi. V primerjavi z laboratorijskimi analizami, je terensko delo hitro in poceni, zahteva manj znanja in strokovne usposobljenosti ter pripomočke, ki so dostopni vsakomur. Zato nas ne čudi, da so za prepoznavanje tipov prsti, priznane in sedaj že uveljavljene mednarodne FAO WRB klasifikacija prsti (Deckers, s sod, 1998; Driessen s sod., 2001, Repe, 2005b), merodajne le tiste lastnosti, ki ji je mogoče določiti na terenu, brez uporabe posebnih pripomočkov in specialnih laboratorijskih analiz.

Da se geografi redko odločimo za proučevanje prsti vsekakor pripomore tudi dejstvo, da so prsti v naravi pod površjem skrite in do informacij se je dobesedno potrebno dokopati. Kje in kako priti do informacij, kaj z njimi početi, ko jih ob potu svojega obraza in z umazanimi rokami vendarle pridobimo, bega marsikaterega študenta, raziskovalca ali učitelja. Izgovore nemalokrat, upravičeno ali neupravičeno, poiščemo v laboratorijskih analizah.

\subsection{Laboratorijske metode proučevanja prsti}

Paleta analiz, ki jih nudi laboratorijsko ugotavljanje lastnosti prsti, je skorajda brezmejna. V grobem jih lahko razdelimo na fizikalne (npr. mehanska analiza) in kemijske (določanje $\mathrm{pH}$ ) analize. Analize pa se razlikujejo tudi glede na pristop (Tan, 2005). Najpogosteje uporabljen je tradicionalen pristop, ko z različnimi postopki (mletje, drobljenje, sejanje, razklop itd.) popolnoma porušimo in premešamo vzorec prsti. Takšen vzorec predstavlja osnovo za večino splošnih fizikalnih in kemijskih analiz, med katere smemo uvrstiti določanje teksture, reakcije, različnih gostot, kapacitet ter vsebnosti vode in zraka, vsebnost organskih snovi, posamezne in skupne količine izmenljivih elementov in še mnoge druge. Naslednji pristop vključuje ekstrakcijo in izolacijo zgolj dela prsti, na katerem nadaljujemo analizo pod (elektronskim) mikroskopom, s termično obdelavo, rentgensko difrakcijo ali infrardečo spektroskopijo. Mikromorfološki ali mikropedološki pristop temelji na opazovanje izjemno tankih slojev prsti pod velikimi povečavami ali opazovanju elektromagnetnega valovanja ob prehodu skozi sloj. 
Zadnji pristop so laboratorijske meritve in situ, ki veliki meri pokriva s terenskimi analizami. Vključuje laboratorijske analize, ki jih merimo neposredno na terenu, na vzorcih, ki so v naravnem okolju (npr. dinamika vode, zraka in hranil v profilu).

Geografsko proučevanje prsti v laboratoriju temelji na tradicionalnem pristopu, $\mathrm{v}$ katerega so vključene vse splošne analize. Z njimi, v kombinaciji s terenskimi ugotovitvami, geografi spoznamo osnovne zakonitosti pedogenetskih procesov ter ugotavljamo povezave s pokrajinotvornimi dejavniki. Obravnava posameznih metod na tem mestu ni primerna, ker so temeljito predstavljene v drugih, tudi geografskih publikacijah (Hemijske..., 1966; Lovrenčak, 1979; Petauer, 1999; Repe, 2000; Repe, 2001; Vovk Korže in Lovrenčak, 2001; Zupan s sod., 2001). Žal pa obenem ugotavljamo, da je uporaba laboratorija kot del proučevanja prsti v geografiji zelo omejena. Delo v (fizičnogeografskem) laboratoriju in analize prsti v večini primerov presegajo geografsko znanje, zato smo odvisni od drugih strok, predvsem kemijske. Oddelek za geografijo na ljubljanski Filozofski fakulteti sicer premore svoj fizičnogeografski laboratorij, katerega opremljenost pa nikakor ni kos večini sodobnim analitičnim standardom, tudi pedološkim. Prirejeni in nestandardni postopki so ob primerni razlagi povsem uporabni pri pedagoškem procesu in za razumevanje osnovnih principov ter procesov. Tudi rezultati dajejo dobro predstavo o lastnostih prsti, kar omogoča razlago položaja prsti v pokrajini, nimajo pa primerljivosti in vsesplošne veljave. Standardne analize, ki bi jih za nas opravile druge inštitucije ali laboratoriji, so izjemno drage in si jih študenti ali samostojni raziskovalci ne morejo privoščiti. Zato moramo prav na tem mestu izpostaviti enega glavnih vzrokov, zakaj v slovenski geografiji prsti tako pogosto izpadejo iz proučevanja.

Finančna plat laboratorijskega proučevanja v slovenski geografiji je resnično velik in težko odpravljiv problem. Odsotnost lastnega, sodobno opremljenega in standardiziranega laboratorija je velik primanjkljaj, še posebej pri ožje specializiranem proučevanju prsti v pokrajini (onesnaženje prsti). Sami tako velikega zalogaja ne bomo zmogli, pa tudi povsem humanistično usmerjena matična ustanova ljubljanskega Oddelka za geografijo, ne bo nikoli pokazal dovolj interesa za razširitev in obogatitev obstoječega laboratorija. Z vidika proučevanja prsti, bi bila umestitev geografije med naravoslovne stroke veliko ugodnejša, saj na takšnih fakultetah ustrezni laboratoriji že obstajajo. Nikakor pa vse našteto ne opravičuje opuščanja proučevanja, saj prav v pedogeografiji lahko marsikatero laboratorijsko analizo nadomestimo s terenskimi ugotovitvami.

\subsection{Sinteza pedogeografskega proučevanja in prikaz rezultatov}

Odločitev, da bomo določen del pokrajine preučili (tudi) z vidika prsti, nas je pripeljala do cele vrste virov in literature, terenskih meritev profilov in njihovih horizontov ter rezultatov laboratorijskih analiz nabranih vzorcev. Skupaj s spoznanji o proučevani pokrajini in teoretično metodološko podlago geografije prsti, je potrebno interpretacije rezultatov povezati v celoto in poiskati sintezne zaključke. Nasproti tehničnemu, v slovenski pedogeografiji prevladuje izrazito genetski pristop pri obravnavi prsti, kar izhaja tudi iz naše pedološke klasifikacije (Lovrenčak, 1994; Prus, 2000). Glavnih tipov prsti, kot osnovnih enot klasifikacije, ne opredeljujemo kvantitativno, z merljivimi parametri (debelina, tekstura, barva, električna prevodnost itd.), 
ampak z dejavniki, ki so vplivali na nastanek in razvoj. Za prsti, ki pripadajo posameznemu tipu, je značilna enaka zgradba profila, zlasti tipično zaporedje horizontov (nastanek, razvoj, izgled in lastnosti so genetsko pogojene). Prsti označujejo enaki osnovni procesi preobrazbe in prenašanja mineralnih in organskih snovi in šele na tretje mesto pridejo kakovostno podobne fizikalno-kemične lastnosti posameznih horizontov. Pristop izhaja iz ruske pedološke šole in ga je v pretežni meri prevzela celotna Evropa. Sam pristop in tudi klasifikacija sama je izrazito geografska, saj sintetizira pokrajinotvorne (pedogenetske) dejavnike v zakrožene celote, tipe prsti. Geografska obravnava prsti v pokrajini pa se ne zadovolji le s prepoznavanjem tipov, ampak želi odgovoriti na vprašanje “zakaj?”.

- Zakaj je nastal določen tip prsti in zakaj prav s tem zaporedjem horizontov?

- Zakaj ravno mestu, ki smo si ga izbrali za proučevanje?

- Zakaj se pojavljajo razlike med posameznimi deli pokrajine?

- Zakaj so nekateri dejavniki in procesi prevladali nad drugimi?

- itd.

Ali če povemo bolj po geografsko, kako so elementi pokrajine vplivali na nastanek in razvoj prsti ter kako prst s svojimi lastnostmi povratno vpliva na pokrajino (slika 1). Tem principom sledi večina del v slovenski geografiji, ki obravnavajo prsti, še posebej je to očitno pri nekaterih delih Vovk Koržetove $(1992,1995,1997)$ in pri predstavitvi pedogeografskih značilnostih posameznih regij, kjer je Lovrenčak povezoval prsti in vegetacijo (1981a, 1981b, 1984, 1987, 1990, 1991, 1999, 2002).

Izrazito sintezen, uporaben in geografskemu proučevanju blizu, je kartografski prikaz ugotovitev našega dela. Tematske karte so eden izmed temeljnih geografskih orodij, ki omogoča prikaz nekega pojava in pri prsteh najpogosteje ugotavljamo njihovo prisotnost v pokrajini oziroma razprostranjenost. Prsti tudi odražajo vplive ostalih naravnih in nekaterih družbenih dejavnikov, zato so zelo primerne za uporabo pri regionalizacijah, še posebej fizičnogeografskih (Lovrenčak, 1991; Vovk Korže, 1995; Lovrenčak, 1996). Upravičeno bi pričakovali, da smo geografi prispevali obilo kartografskega gradiva, ki prikazujejo prsti določenih delov Slovenije. Ne moremo se bolj motiti. Resda vsebujejo prispevki, raziskave, regionalizacije, vrednotenja pokrajine, seminarske naloge, diplomska in magistrska dela kar precej kartografskega gradiva o prsteh ali pedosekvecah, ki pa so vsa po vrsti povzeta, predvsem iz pedološke stroke. Najpogosteje po Osnovni pedološki karti SFRJ 1:50.000 (Stepančič s sod., 1986), redkeje po pedološki karti Slovenije 1:25.000 (Rupreht s sod., 1994) ali Agrokarti Slovenije (Kocjančič s sod., 1987), nekaj kartografskega gradiva je prispeval tudi Inštitut za hmeljarstvo in pivovarstvo Žalec (npr. Hidropedološka..., 1986). Noben od pregledanih geografskih prispevkov ne vsebuje podatkov digitalne pedološke karte 1:25.000. Po eni strani je povzemanje povsem razumljivo. Geografska stroka v Sloveniji ni uradno kompetentna za področje kartiranje tal (prsti) in to delo opravljajo pedologi. Neupravičeno bi bilo pričakovati, da bi geografi ponavljali že opravljeno delo. Po drugi strani pa pedogeografska proučevanja na mikro in mezo nivoju opozarjajo na razhajanja s pedološkimi kartami 1:50.000 in 1:25.000. Obilica izkopanih profilov nakazuje na drobne ali tudi velike razlike v pokrajinski odeji prsti, ki na objavljenih kartah niso zabeležene. Takšne ugotovitve bi nedvomno bistveno pripomogle $\mathrm{k}$ poznavanju prsti $\mathrm{v}$ Sloveniji in izdelava posodobljenega kartografskega gradiva bi dala slovenski pedogeografiji veliko večjo veljavo. Obenem je na tem mestu ponovno potrebno 
opozoriti na dejstvo, da so tiskane in digitalne pedološke karte skorajda nedostopne.

Za geografske, avtorske karte zadostujejo prsti ene roke, avtor pa je le en sam. Lovrenčak je prispeval pregledno karto prsti Slovenije, ki je objavljena na več mestih (Lovrenčak, 1998a; Lovrenčak, 1998a; Repe, 2004). Poleg tega je Lovrenčak izdelal še dve pedološki karti, ki sta rezultat podrobnega geomorfološkega, litološkega in pedološkega kartiranja teras v zgornjem Posočju (Lovrenčak, s sod., 1978a, str. 281 in 1978b, 304).

Razlogov, zakaj slovenski geografi ne prikažemo rezultatov proučevanja prsti na kartah niti takrat, ko bi imeli za to upravičene razloge, je verjetno več. Poleg že obstoječih pedoloških kart, je krivec nizka samozavest. Neupravičene zadrege se pogosto pojavijo že ob terenskem proučevanju in kasneje pri sintezni razlagi ugotovitev. Usposobljenost izdelave avtorske karte razprostranjenosti prsti v pokrajini nam načenjajo naslednji dvomi:

- Geografi nimamo dovolj teoretičnega znanja in praktičnih izkušenj o zakonitostih prostorske diferenciacije odeje prst.

- Izdelava karte prsti določenega dela pokrajine zelo zahtevna in zapletena.

- Karta ne bo popolnoma odražala realnega stanja v pokrajini.

- Meja med dvema tipoma prsti pogosto ni ostra, ampak predstavlja pas, območje. Geografi zato ne bomo znali razmejiti dveh tipov prsti. Poleg tega naše odločitve ne bomo znali utemeljiti.

- Lastnosti prsti se v naravi spreminjajo izrazito zvezno, na kartah pa jim vsiljujemo diskretne enote.

- Za določevanje tipov, razmejevanje in učinkovito posploševanje imamo premalo terenskih podatkov in laboratorijskih analiz.

- Hkratno in močno součinkovanje pedogenetskih procesov in pedogentskih dejavnikov zapleta možnost razlage vzorca prsti v pokrajini, ob čemer marsikaterega dejavnika sploh ne poznamo.

- Kako bomo izrazito točkasto proučevane lastnosti in tipe uspešno posplošili na celotno pokrajino?

- Naši rezultati se ne bodo ujemali z ugotovitvami na pedoloških kartah, kar pomeni, da so napačni.

- itd.

Marsikateri izmed dvomov, se pojavlja tudi v drugih vejah geografije, sorodnih vedah in tudi pri pedologih, pa raziskovalcev ne zaustavijo. Nekateri pomisleki so upravičeni, večina ne. Ampak ne glede na vse skupaj, bi se morali slovenski geografi pogosteje lotevati tudi izdelave kart prsti. Vse našteto je mogoče do neke mere nadomestiti z geografskim pristopom proučevanja, uporabo lahko dostopnih digitalnih podatkov in kartografskega gradiva, enostavnega terenskega proučevanja, v kombinaciji s sorazmerno preprostimi GIS orodji ter kvantitativnimi metodami. S tem bomo preskočili marsikatero finančno ali časovno oviro in pridobili dragocene informacije o prsteh v pokrajini na način, ki je geografom blizu in domač. Uporaba geografskih informacijskih sistemov in kvantitativnih metod pri obravnavi pojavov in procesov v pokrajini, njihova razlaga in interpretacija ter na koncu tudi kartografski prikaz se je v slovenski geografiji začela uveljavljati sorazmerno zgodaj. Sledove uporabe sodobnih, kvantitativnih metod je dandanes mogoče zaznati skorajda pri vsaki geografski raziskavi. Prednosti, ki jih nudijo geografski informacijski sistemi in računalniško podprta kartografija, 
omogočajo tudi uspešno soočenje z ovirami in težavami pri proučevanju prsti (Burrough in McDonnell, 1998, str. 7):

1. Hitra izdelava kart.

2. Cenejša izdelava kart.

3. Izdelava kart, ki ustrezajo povsem specifičnim potrebam.

4. Možnost izdelave kart tudi v primerih, ko ne razpolagamo s strokovno usposobljenimi kadri.

5. Omogočajo grafično eksperimentiranje ter modeliranje na podlagi istih ali sorodnih baz podatkov.

6. Omogočajo in pospešijo posodabljanje kart, na podlagi podatkov v digitalni obliki.

7. Omogočajo analize podatkov, ki zahtevajo součinkovanje med statističnimi analizami in kartografijo.

8. Zmanjšajo uporabo tiskanih kart, kot obliko shranjevanja podatkov, s čimer zreduciramo učinke klasifikacij in generalizacij in tako ohranjamo kvaliteto podatkov.

9. Ustvarjanje kart, ki jih človek zelo težko izdela (npr. 3D kartografija).

10. Ustvarjanje kart, kjer so vsi postopki natančno opredeljeni in brez izjem dosledno izpeljani.

11. Avtomatizacija procesov omogoča stalen nadzor, sprotno popravljanje napak in poljubno število ponovitev.

Na koncu lahko še dodamo, da lahko z računalnikom modeliramo poljubno število dejavnikov, faktorjev in vplivov, upoštevamo vsako podrobnost in za vsak rezultat, ki ga dobimo, obstaja logična in kvantitativno podprta razlaga.

\subsection{Primer uporabe geografskih informacijskih sistemov in kvantitativnih metod pri izdelavi karte prsti v krajinskemu parku Lahinja v Beli krajini}

Proučevanje prsti v krajinskem parku Lahinja smo se lotili po klasičnem pristopu, ki je bil predstavljen v prejšnjih poglavjih (slika 1), v okviru študentskih terenskih vaj v Beli krajini v letih 2003 in 2004. Z vidika prsti, je bil glavni namen terenskih vaj:

- $\quad$ seznanitev študentov s terenskimi metodami proučevanja prsti, jemanjem vzorcev,

- $\quad$ iskanje ter razlaga povezav njihovih ugotovitev z opazovanji na terenu,

- prepoznavanje poglavitnih pedogenetskih procesov in pedogenetskih dejavnikov.

Cilj terenskih vaj bil ugotoviti in predstaviti prostorske zakonitosti pojavljanja ugotovljenih tipov prsti.

Skopa literatura o sorazmerno majhnem območju (266 hektarov) nam je razkrila le nekaj zelo splošnih ugotovitev. Da je krajinski park Lahinja posebnost Bele krajine, še posebej kar se tiče njegovih vodnih in rastlinskih značilnosti (Perko in Orožen Adamič, 1998). Uravnan relief z nizkimi strmci, ki ga prekrivaje mlade, drobne naplavine v samem povirnem delu reke Lahinje ter potoka Nerajčice, so povzročili zastajanje vode in zamočvirjenost najnižjih delov parka. Na dnu parka prevladujejo kmetijske in travniške površine, ki so ponekod v opaznem 
zaraščanju. Bolj razgibano in rahlo vzpeto obrobje prerašča gozd. V času terenskih vaj, poleg temeljnih topografskih načrtov 1:5.000 in Osnovne geološke karte 1:100.000, nismo razpolagali z nobenim drugim kartografskim gradivom. Glavna orientacija, vodilo in načrt proučevanja prsti so bili matična podlaga (geološka karta) ter terenska opazovanja reliefa, vod in rabe tal, ki smo jih označili kot glavne pedogenetske dejavnike.

V krajinskem parku Lahinja prevladujejo apnenci in dolomiti jurske ter kredne starosti z mnogimi fosilnimi ostanki in so značilni za osrednji del parka. Prekrivajo celotno višje obrobje na vzhodu, jugu in severu ter delno tudi na zahodu, kjer pa v severozahodni smeri preidejo v pliokvartarni konglomerat. Hkrati so to tudi najbolj vzpeti in zakraseli deli krajinskega parka, še posebno v južnem delu, kjer so značilna reliefna oblika vrtače, pogosti so kraški izviri in celo brezna. Na jugozahodnem delu krajinskega parka je relief zopet bolj uravnan, saj na površju pas rdečih boksitnih glin prekinja karbonatno matično podlago (Tumač za list Črnomelj, 1984). Holocenske naplavine ob reki Lahinji se ob prelomu v dinarski smeri vlečejo čez celoten osrednji del. Ob potoku Nerajčica se območje holocenskih naplavin precej razširi proti zahodnem delu parka. Zelo ozek pas spremlja nato Lahinjo na njeni poti naprej proti severu, kjer le ta v nekaj večjih okljukih prebije kredne apnence in nadaljuje svojo pot izven območja krajinskega parka proti izlivu v reko Kolpo.

Površje je v grobem slabo razgibano, mikroreliefno pa precej bolj. Razgibano ni le obrobje, marveč sta tudi južni in severni del precej vzvalovljena in vrtačasta. Kar se tiče reliefa lahko zaključimo, da je zelo uravnanega površja sorazmerno veliko, zelo malo pa je povsem ravnih predelov. Hiter pogled na topografsko karto razkrije tudi zelo majhno reliefno energijo. Razlika med najmanjšo nadmorsko višino na samem robu parka (145 m), kjer ga zapušča Lahinja in najvišjo točko na jugovzhodnem obrobju (206 m) znaša komaj nekaj nad 60 metrov. Z izjemo zahodnega obrobja, se v parku ne pojavljajo večji nakloni, zato smo predvidevali, da ekspozicija ne bo bistveno vplivala na lastnosti prsti.

Večkrat prehojeno območje krajinskega parkaje razkrilo tudi vodne in vegetacijske poteze. Posebnost krajinskega parka Lahinja je vsekakor osrednja uravnava, po kateri tečeta Lahinja in Nerajčica. Znotraj uravnave sta tudi dva zamočvirjena predela, Lahinjske in Nerajske luge. Nakloni so tu minimalni, strmci obeh rek so zelo majhni, tok vode je počasen in talna voda je zelo blizu površja. S pomočjo vrtin pedološkega svedra smo na talno vodo naleteli na globinah nekaj desetih centimetrov, na dveh lokacijah pa se je pojavila prav na površju. Oba vodotoka tečeta po holocenski naplavini, ki je aluvialnega nastanka, na vzhodnem robu pa smo ugotovili pomešanost s koluvialnim gradivom. V krajinskem parku v glavnem prevladujejo ekstenzivni travniki, ki se razraščajo po celotnem parku, predvsem na uravnanih delih. Prevlado travnikov je mogoče utemeljiti z izsekavanjem gozda za potrebe kmetijstva in pašništva, ponekod pa so zemljišča preveč mokrotna. Med travniki se pojavljajo posamezne zaplate zelo tipičnih steljnikov z navadno brezo (Betula pendula) in orlovo praprotjo (Pteridium aquilinum), ki pa se ponovno zaraščajo s prvotno vegetacijo. Sklenjene gozdne površine prevladujejo predvsem na vzhodnem obrobju, kjer uspeva gozd belega gabra (Carpinus betulus), skupaj s hrastom gradnom (Quercus petraea), primešani so pogosto še enovrati glog (Crataegus monogyna), rumeni dren (Cornus mas), trepetlika (Populus tremula), maklen (Acer campestre), navadna breza (Betula pendula) in rdeči bor (Pinus sylvestris). Na prehodu iz pobočja v ravnino se gabrovemu sestoju začne pridruževati hrast dob (Quercus robur). Ob vodotokih ter v lugih 
uspevajo sestoji črne jelše (Alnetum glutinosae), vrb (Salicetum), v podrastju uspeva trstičje (Phragmites australis) s šaši (Carex sp.).

Slika 4: Geološko zaledje in topografska podlaga krajinskega parka Lahinja

Picture 4: Geology and topography of the Lahinja landscape park

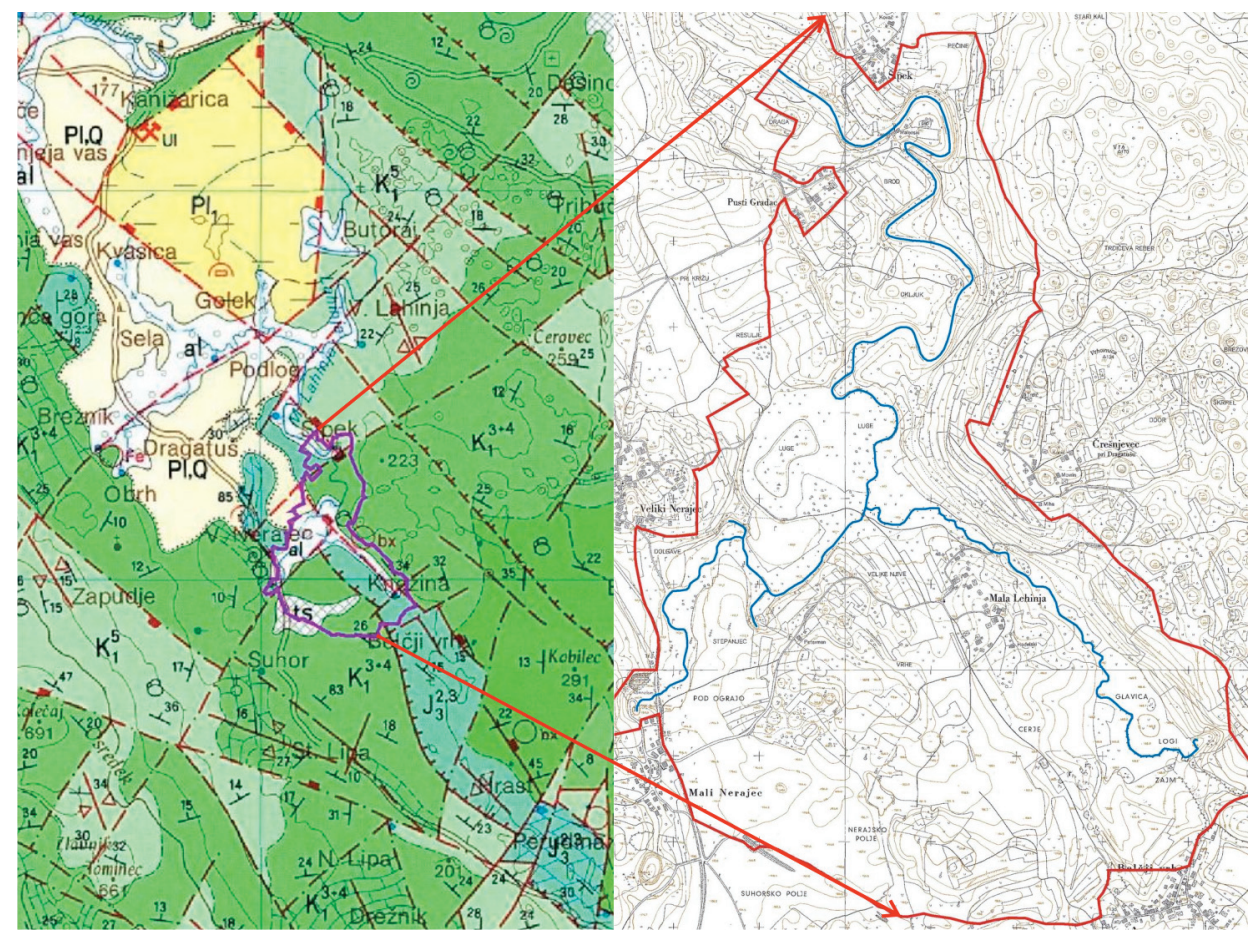

Vir: Osnovna geološka karta SFRJ, list Črnomelj 1:100.000, 1972 in Temeljni topografski načrt 1:5.000, 2004

V dveh zaporednih letih smo glede na opazovane pokrajinske dejavnike natančno proučili 35 lokacij znotraj parka. Na vsaki izmed lokacij je bila izkopana profilna jama do matične podlage, če le ta ni bila globlje od $70 \mathrm{~cm}$. V tem primeru smo do matične podlage prišli z vrtino pedološkega svedra. Sveder smo uporabili tudi za jemanje vzorcev pod gladino talne vode. Za vsako proučevano mesti smo opravili naslednje terenske meritve in opazovanja:

- Opis lokacije profilne jame:

- $\quad$ na topografski karti in GPS smo zabeležili lokacijo izkopa;

- na podlagi geološke karte in izkopanega vzorca smo določili matično podlago;

- $\quad$ izmerili smo naklon in ekspozicijo, nadmorska višina je bila odčitana s topografskega načrta;

- določili smo prevladujočo reliefno obliko ter naredili skico (prerez) lokacije in njene okolice; 
- $\quad$ na vsaki lokaciji smo popisali rastlinske vrste po Braun-Blaquetovi metodi;

- zabeležena sta bila tudi datum in opisovalec;

- $\quad$ vsaki lokaciji smo dodelili unikatno signaturo, ki jo je sestavljalo leto proučevanja, črka skupine študentov in zaporedna številka proučevane lokacije (npr. 2004_A_09).

- Opis profila in horizontov prsti:

- Oznaka vseh ugotovljenih horizontov od površja do matične podlage oziroma talne vode.

- Za vsak horizont posebej smo izmerili/določili/ocenili (če ni navedeno drugače, Vovk Korže in Lovrenčak, 2004): globino (debelino), barvo (Munsell soil colour chart, 1992), teksturni razred s prstnim preizkusom, delež skeletnih delcev, vlažnost, reakcijo s tekočim in papirnatim indikatorjem v $0,1 \mathrm{~N} \mathrm{KCl}$, delež kalcijevega karbonata na podlagi vidnih in slušnih znakov ter zabeležili vidne posebnosti (konkrecije, prekoreninjenost, rovi živali itd.). Če je vzeti vzorec dopuščal, smo določili tudi strukturo in obstojnost strukturnih agregatov po Sékeri.

- Določili smo tip prsti, ter profil skicirali ali fotografirali.

Slika 5: Lokacije proučevanja prsti v krajinskem parku Lahinja

Picture 5: Location of soil samples in the Lahinja landscape park

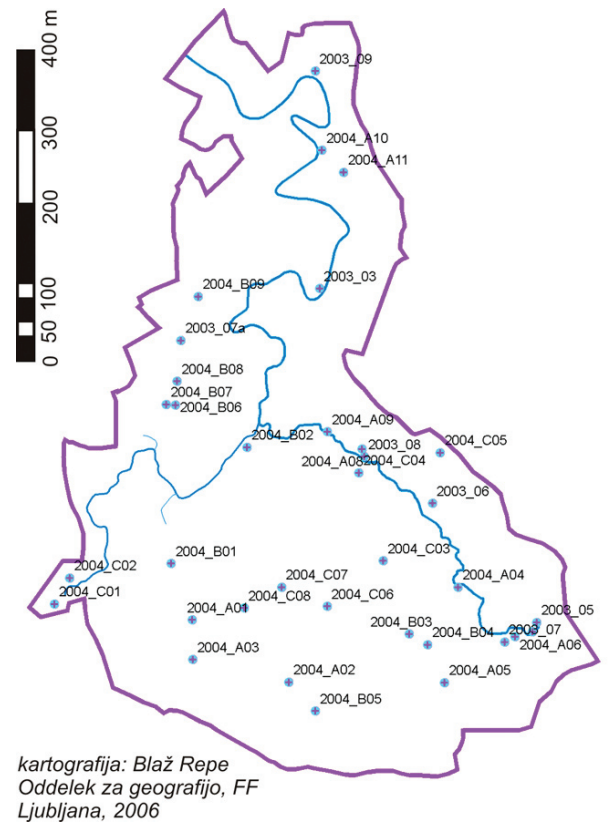

Vir: terensko delo 2003/04 
Slika 6: Tipi prsti in njihova razprostranjenost v krajinskem parku Lahinja na podlagi terenskih opazovanj in meritev ter laboratorijskih analiz

Picture 6: Soil types and units in the Lahinja landscape park according to field survey and laboratory analysis

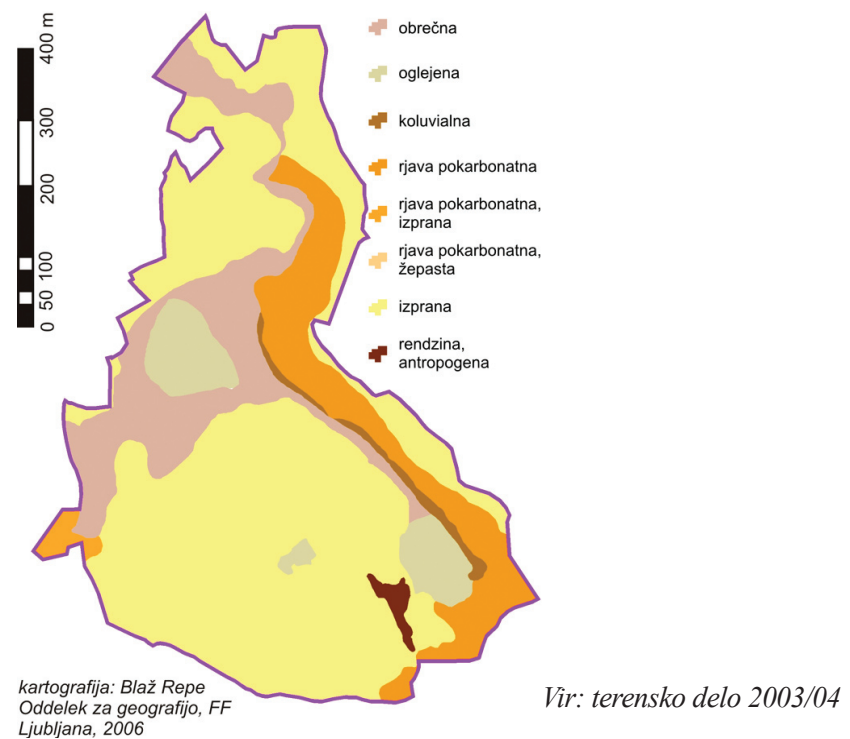

- Jemanje vzorcev:

- $\quad Z a$ analizo v laboratoriju smo vzeli vzorce iz vsakega prepoznanega horizonta. Poleg unikatne signature profila, je vsak vzorec dobil še zaporedno številko horizonta, od površja proti matični podlagi (npr. 2004_A_09_1, 2004_A_09_2. itd.).

- $\quad \mathrm{Na}$ zraku posušene vzorce smo zdrobili $\mathrm{v}$ mlinu in presejali skozi sito $2 \mathrm{~mm}$ in $\mathrm{v}$ fizičnogeografskem laboratoriju Oddelka za geografijo v Ljubljani z analizami določili naslednje parametre (Vovk Korže in Lovrenčak, 2001): teksturo (mehanska analiza z mokrim sejanjem in pipetiranjem po Köhnu), elektrometrično merjene $\mathrm{pH}$ v $0,1 \mathrm{~N} \mathrm{KCl}$, delež karbonatov s scheiblerjevim kalcimetrom in delež organske snovi s suhim sežigom.

Na podlagi predvsem terenskih opazovanj smo prepoznali in ugotovili sledeče tipe prsti:

- obrečne in koluvialne prsti,

- oglejene prsti,

- rjave pokarbonatne prsti,

- rendzine,

- izprane prsti (steljniške) in

- antropogene prsti.

Glede na matično podlago bi v krajinskem parku upravičeno pričakovali razvoj pedosekvenc na trdi karbonatni matični podlagi (Stritar, 1990), ki pa zaradi lege samega parka 
in reliefa znotraj njega niso popolnoma razvite. Odsotnost večjih strmin je vzrok, da smo pri proučevanju prsti zelo redko naleteli na rendzine, ki za območje parka niso značilne. Isti vzrok pogojuje močno prepletenost ostalih enot.

\section{Slika 7: Pedosekvence v krajinskem parku Lahinja}

Picture 7: Sequence of soils in the Lahinja landscape park

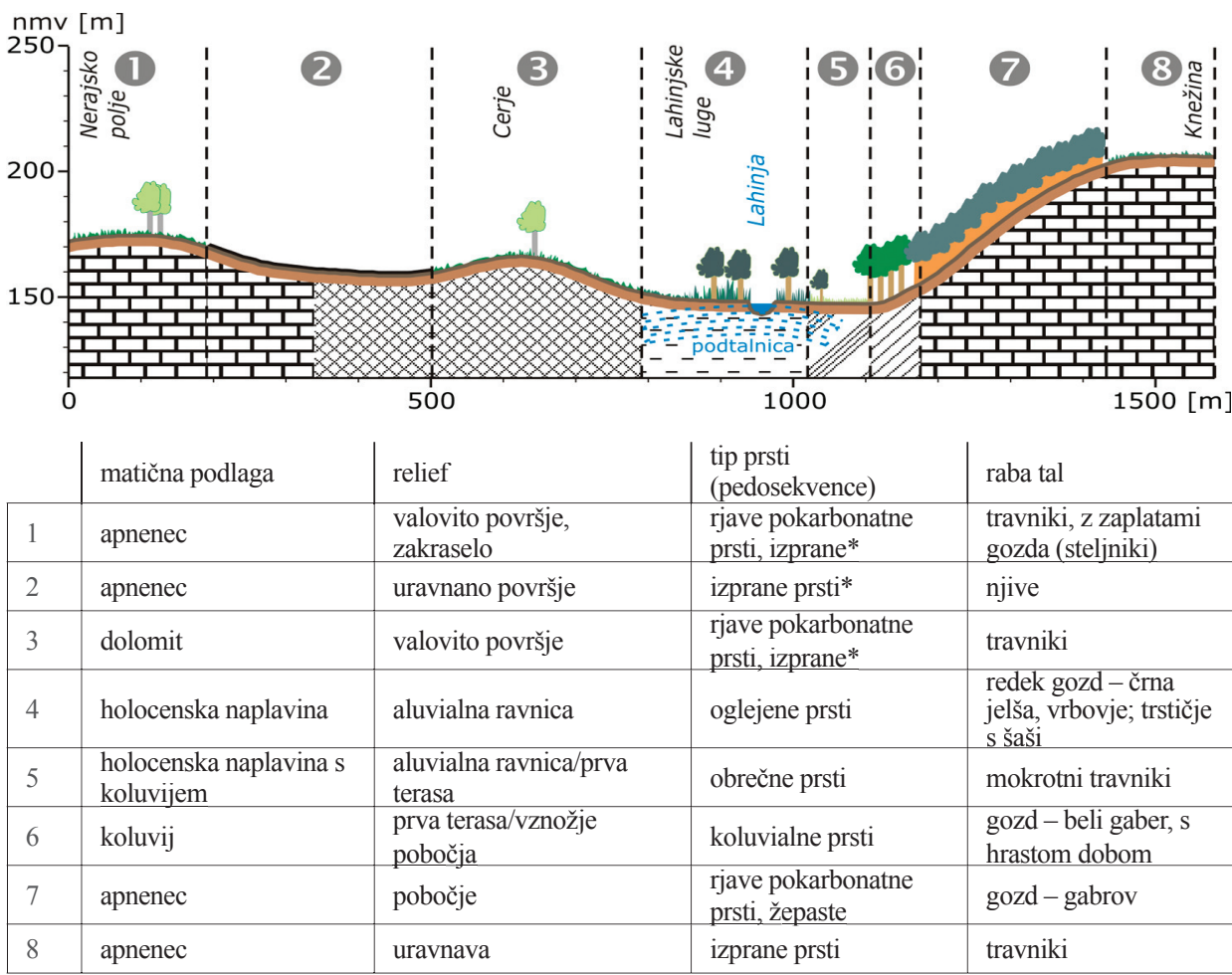

* - izprana varianta rjavih pokarbonatnih se izrazito prepleta z izpranimi prstmi

Vir: Terensko delo, 2003/04

Točkasta terenska spoznanja o profilih prsti in njihovih lokacijah ter rezultati laboratorijskih analiz so bili podlaga za proučevanje zvez med tipi prsti in matično podlago, reliefom, vodnimi razmerami, vegetacijskim pokrovom in rabo tal (slika 7). Zaradi majhnih horizontalnih in vertikalnih razsežnosti ${ }^{5}$ ter majhne razgibanosti reliefa, podnebja, kot tudi ne mikroklime nismo upoštevali kot pedeogenetski dejavnik. Podnebje se odraža v nekaterih pedogenetskih procesih, ki so značilni za ta del Slovenije (preperevanje matične podlage,

\footnotetext{
${ }^{5}$ Krajinski park se razprostira 2,6 km v smeri S-J in 2,0 km v smeri V-Z, najvišja točka parka je na nadmorski višini $206 \mathrm{~m}$, najnižja pa na $147 \mathrm{~m}$.
} 
argilogeneza in braunizacija, humifikacija, izpiranje baz(hranil) in glinastih delcev, oglejevanje) in ne le za krajinski park. Na podlagi proučenih zvez in ugotovljenih pedosekvenc smo izdelali karto prsti krajinskega parka (slika 6). Obrečne prsti se pojavljajo na uravnanem delu parka, ki ga prekrivajo mladi aluvialni nanosi ter spremljajo oba vodotoka. Na vzhodnem obrobju obrečne prsti prehajajo v koluvialne prsti, te pa na pobočju, na trdih karbonatnih kamninah $\mathrm{v}$ rjave pokarbonatne prsti, ki imajo žepast značaj. Rjave pokarbonatne prsti se pojavljajo tudi na uravnanih delih parka, kjer nastopajo v tipični in izprani obliki, izrazito pa se prepletajo z izpranimi prstmi. Največ izpranih prsti je na območju, kjer so geologi prepoznali rdeče boksitne gline. Na zamočvirjenih območjih najnižjega dela parka, ki jim domačini pravijo Luge (Nerajske in Lahinjske), so sklenjeno oglejene prsti. Na naravne rendzine smo naleteli le $\mathrm{v}$ enem primeru in se na karti ne pojavljajo, z izjemo antropogene zaplate, na opuščenem peskokopu.

Terenska opazovanja so pokazala zelo tesno prepletanje posameznih tipov prsti, še posebej različnih podtipov rjavih pokarbonatnih prsti (tipičnih, globokih in izpranih) in izpranih, steljniških prsti. Samo na podlagi točkastih proučevanj je takšno pestrost zelo težko prikazati, zato smo se odločili za podrobnejšo (geo) statistično analizo digitalnih podatkov, ki smo jih dodatno pridobili, posodobili ali izdelali:

- Dopolnili in s terenskimi ugotovitvami smo popravljena geološko podlago (slika 8).

- Ker se je digitalni model nadmorskih višin z velikostjo celice $25 \times 25 \mathrm{~m}$ izkazal za veliko pregrobega na tako majhnem območju, smo na podlagi digitaliziranih plastnic iz temeljnega topografskega načrta 1:5.000 izdelali nov model nadmorskih višin $5 \times 5 \mathrm{~m}$. Iz podrobnejšega modela nadmorskih višin smo izdelali površji naklonov in ekspozicij enake natančnosti (slika $9,10,11$ ).

- Za lažjo in podrobnejšo identifikacijo vodnih značilnosti ter vegetacijskega pokrova smo uporabili digitalne ortofoto posnetke, kot tudi 7 slojev Landsatova TM satelita (orthorectificirani multispectralni in pankromatski posnetki, Landsat 7 ETM+). Slednji so se prav tako izkazali za pregrobe in manj uporabne (slika 12).

- Podlaga za rabo tal nam služil vektorski sloj pokrovnosti MKGP (slika 13).

Novi digitalni sloji podatkov so omogočili izračuni nekaterih dodatnih kvantitativnih opredelitev krajinskega parka:

- Najpogostejša matična podlaga so aluvialne naplavine, ki se pojavljajo na 66,8 hektarih. Sledijo kredni apnenci in dolomiti na 128,4 hektarih, nato jurski na 39,9 hektarih, rdeče boksitne gline na 18,0, na 7,7 hektarih vznožji pobočij so identificirali koluvij, najmanj je pliokvartarnih nanosov in sicer 5,1 hektar (slika 14).

- Povprečna nadmorska višina v krajinskem parku je 160 metrov. Najstrmejše pobočje je nagnjeno zgolj za $25^{\circ}$, medtem ko je povprečni naklon $5,5^{\circ}$, najobsežnejši naklonski razred je $0-5^{\circ}\left(56 \%\right.$, do $10^{\circ}$ pa je kar $85 \%$ površja). Z izjemo vzhodnega obrobja ekspozicije niso izrazite in nobena posebej ne izstopa (ravnina - 11,3\%, severna - 14,1\%, vzhodna - 20,0\%, južna - 20,5\% in zahodna - 34,0\%).

- Nerajčica je dolga $1380 \mathrm{~m}$ in do izliva v Lahinjo naredi le $8 \mathrm{~m}$ višinske razlike, tok Lahinje v samem parku je dolg $4515 \mathrm{~m}$, na tej razdalji pa se od izvira spusti za 11 metrov.

- Med kategorijami pokrovnosti je daleč največ travniških površin, gozdne in njivske površine so približno enake, kar velik je delež površin v zaraščanju (4\%) (slika 15). 
Slika 8: S terenskimi ugotovitvami dopolnjena geološka podlaga krajinskega parka Lahinja Picture 8: Through soil survey updated geology map of the Lahinja landscape park

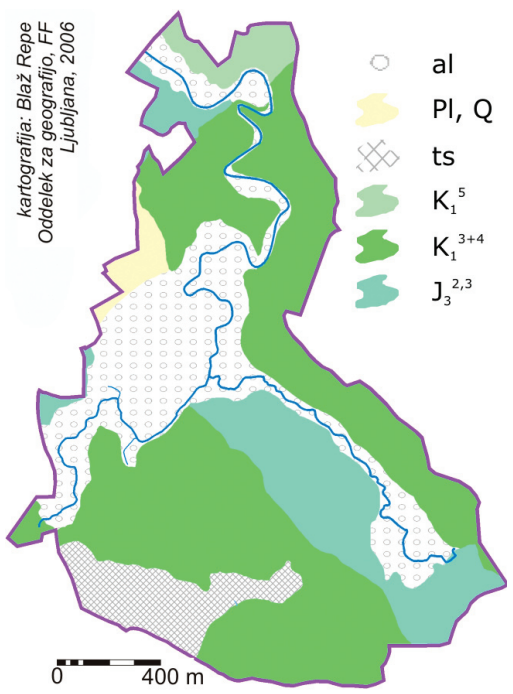

Vir: Osnovna geološka karta SFRJ, list Črnomelj 1:100.000, 1972 in terensko delo 2003/04

Slika 9: Digitalni model nadmorskih višin $5 \times 5 \mathrm{~m}$

Picture 9: Digital elevation model $5 \times 5$ meters

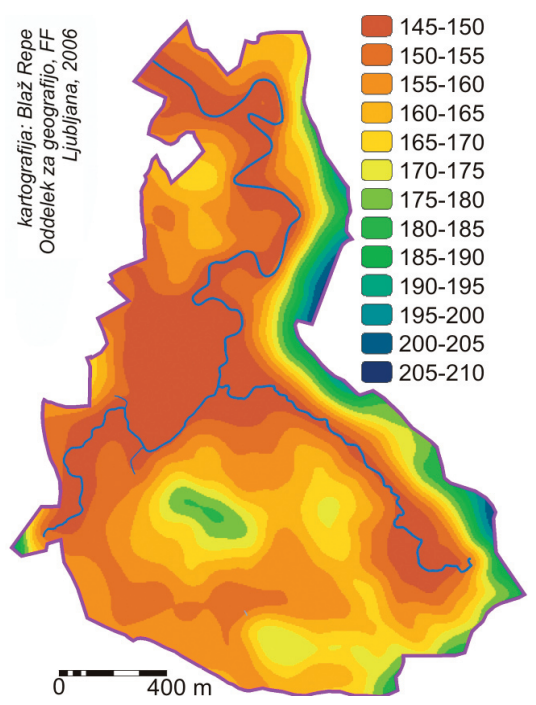

Vir: Temeljni topografski načrt 1:5.000, 2004 
Slika 10: Nakloni pobočij $5 \times 5 \mathrm{~m}$

Picture 10: Inclination of slopes $5 \times 5$ meters

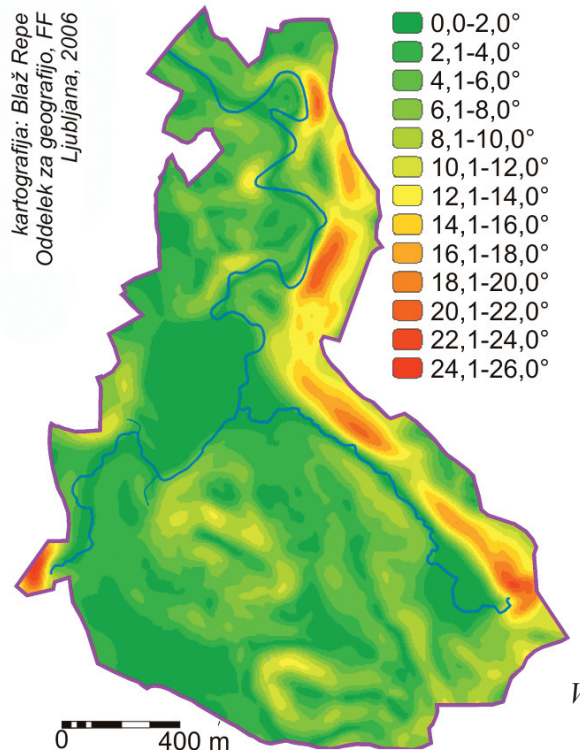

Vir: Temeljni topografski načrt 1:5.000, 2004

Slika 11: Ekspozicije pobočij $5 \times 5 \mathrm{~m}$

Picture 11: Exposition of slopes $5 \times 5$ meters

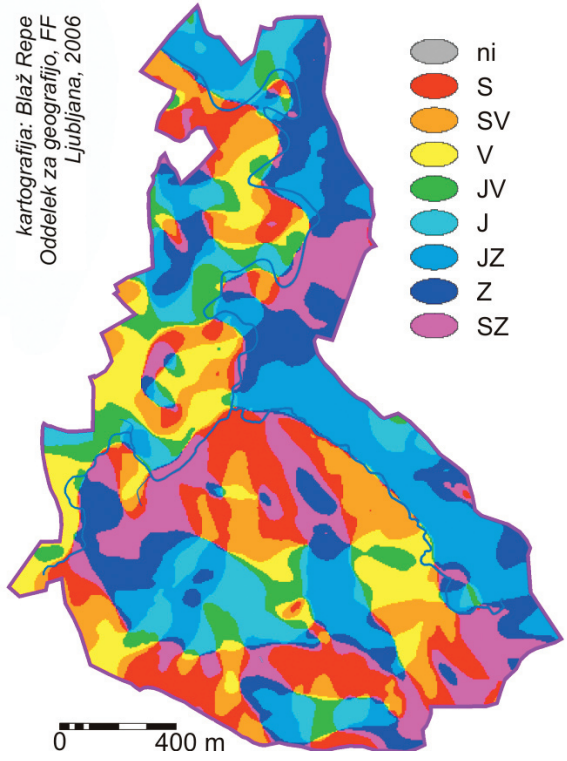

Vir: Temeljni topografski načrt 1:5.000, 2004 
Slika 12: DOF krajinskega parka Lahinje s profili in tipi prsti

Picture 12: Digital ortorectified aerial images of the Lahinja landscape park with soil profile locations

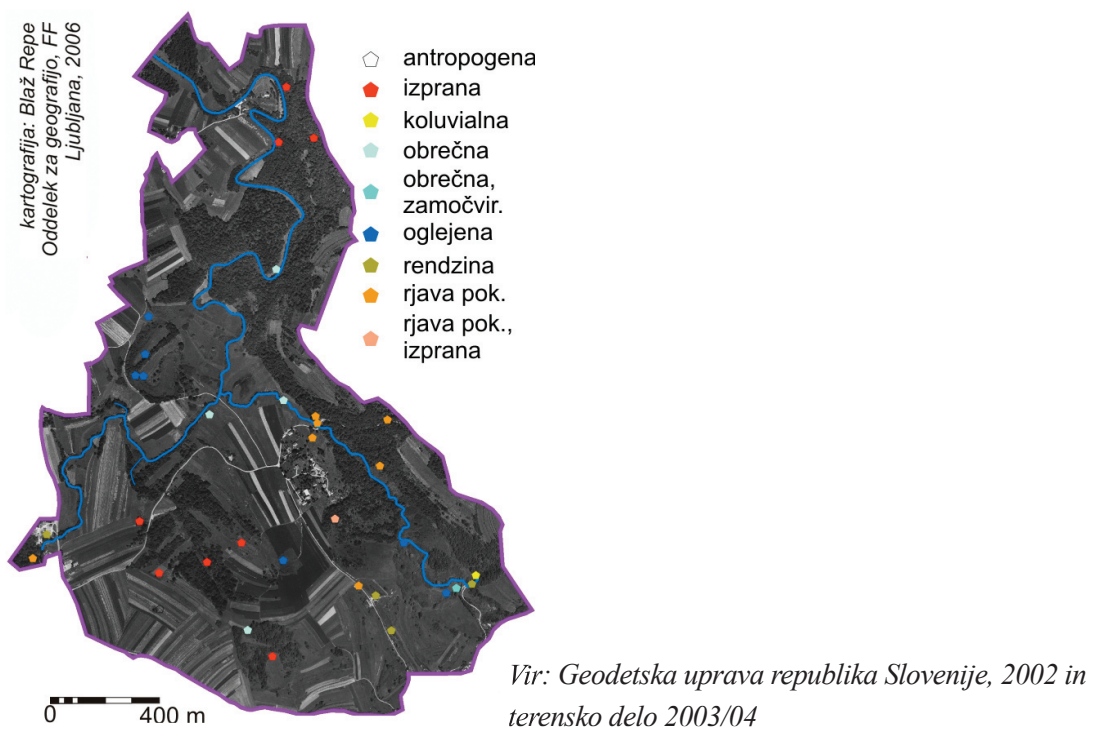

Slika 13: Pokrovnost in raba tal MKGP

Picture 13: Land use of the Lahinja landscape park

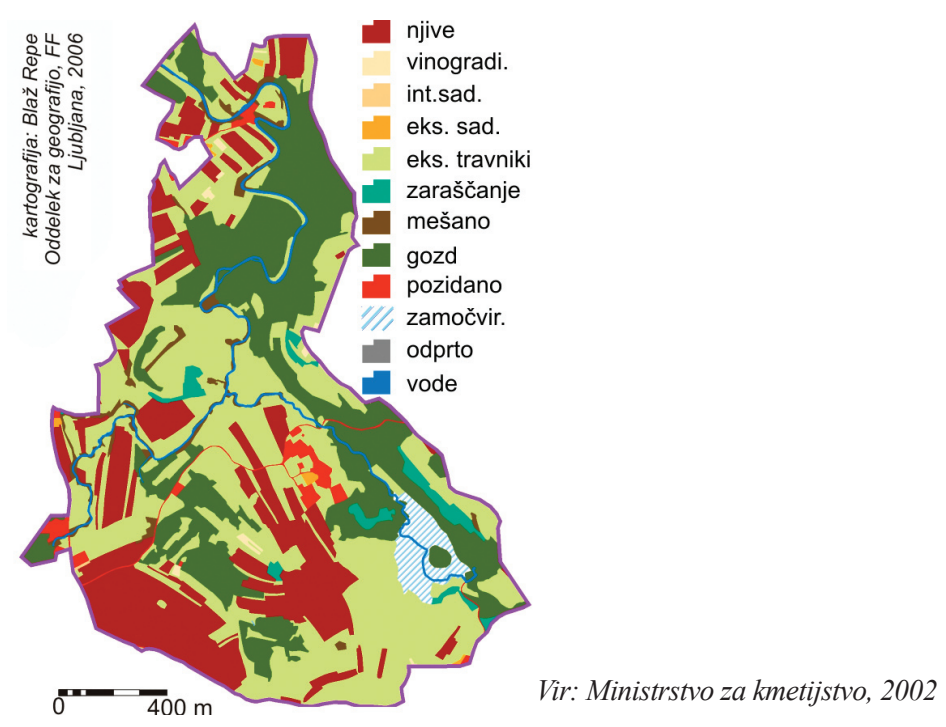


Slika 14: Deleži matične podlage v krajinskem parku Lahinja

Picture 14: Parent material percentages in the Lahinja landscape park

$3 \%$

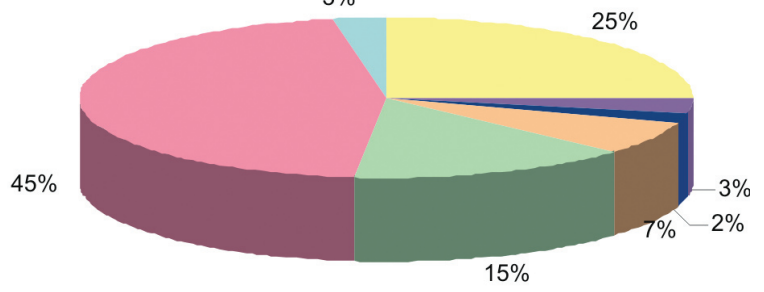

aluvij $₫$ koluvij $₫ \mathrm{PI}, \mathrm{Q}$ boksitne gline $-\mathrm{J}_{3}^{2,3}=\mathrm{K}_{1}^{3+4}=\mathrm{K}_{1}^{5}$

Vir: Osnovna geološka karta SFRJ, list Črnomelj 1:100.000, 1972 in terensko delo 2003/04

Slika 15: Razmerje med kategorijami pokrovnosti v krajinskem parku Lahinja

Picture 15: Percentages of land use categories in the Lahinja landscape park

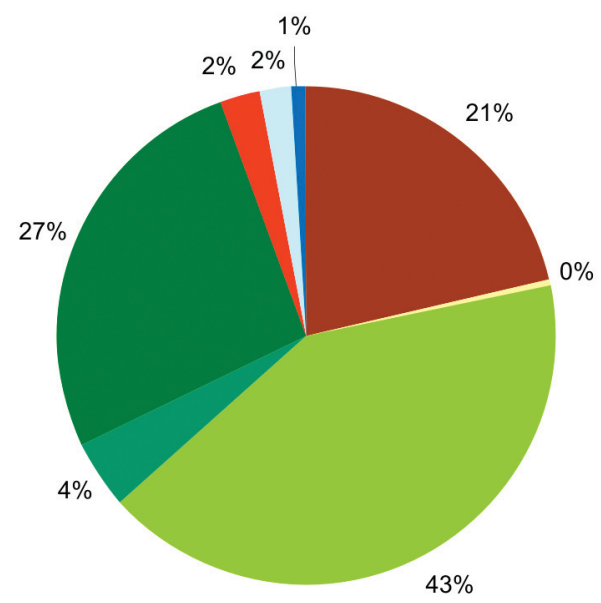

- Njive in vrtovi

Vinogradi

- Travniki

Zaraščanje

- Gozd

- Pozidano

Zamočvirjeno

- Vode

Digitalni podatki, ki smo jih pridobili kažejo na veliko večjo pestrost pedogenetskih dejavnikov, kot smo jih opazili s terenskim opazovanjem. Na pestrost in močno prepletanje različnih tipov pokarbonatnih prsti ter izpranih smo sicer opozorili, nismo pa mogli tega prikazati. Za prikaz razprostranjenosti prsti bomo uporabili tri metode ${ }^{6}$ :

\footnotetext{
${ }^{6}$ Za modeliranje slojev podatkov smo uporabili programska paketa Idrisi 3.2 in ArcGIS 9.1, kartografsko in slikovno gradivo je bilo pripravljeno s paketom Corel Graphics Suite 11.
} 
- multivariatno hierarhično klasifikacijo (cluster in isoclust),

- multivariatno nadzorovano klasifikacijo satelitskih posnetkov (maximum likehood) in

- in prostorsko interpolacijo točkastih meritev (kriging).

Postopke multivariatnih razvrščanj in uvrščanj v skupine smo prevzeli iz metodologije trdih klasifikacij satelitskih posnetkov (hard classifiers), kjer vsaki celici enoznačno pripišemo razred (Lillesand in Kiefer, 1994) oziroma najpogosteje kategorijo pokrovnosti. Vsi postopki klasifikacije potekajo v rastrskem načinu, kar pomeni za vsako (5 metrsko) celico posebej. Na podlagi razpoložljivih slojev podatkov in njihovih statističnih parametrov, želimo vsaki celici pripisati razred, v našem primeru je to tip prsti. Glavna principa klasifikacij sta dva, nenadzorovane klasifikacije ali razvrščanje v skupine ter nadzorovane klasifikacije ali uvrščanje v skupine.

Pri nenadzorovanih klasifikacijah postopek išče "naravne" skupine (clustre), ki se pojavljajo v populaciji, glede na izbrane spremenljivke. Klasifikacija je nenadzorovana, ker razen z izborom števila skupin, ne moremo vplivati na razvrščanje. Klasifikacija je prostorsko neodvisna in sosednje enote ne vplivajo druge na drugo (Campbell, 2002). Pri razvrščanju enot v skupine (tipe prsti), glede na pedogenetske dejavnike, simuliramo izkustveni postopek, ki ga sicer miselno opravimo, ko razmejujemo tipe prsti na kartografski podlagi. Prednosti digitalnega razvrščanja so hitrost, nepristranskost, natančnost (kolikor so natančni vhodni podatki) in sposobnost iskanja podobnosti med skoraj poljubnim številom dejavnikov. Interpretacija dobljenih skupin poteka na podlagi statistične analize posameznih spremenljivk znotraj skupine in/ali v kombinaciji s terenskimi opazovanji. Pri tem postopku predpostavljamo dejstvo, da so na podobne tipe prsti vplivali isti dejavniki podobno ali enako močno. Klasifikacija bi morala izločiti naravna območja, kjer bi morale biti tudi tipi prsti sorazmerno homogene, glede na vhodne podatke.

V primeru dveh parametrov (razvrščanje sicer poteka na podlagi izbranega $n$-števila dejavnikov, v pripadajočem n razsežnem vektorskem prostoru), bi v ravninskem koordinatnem sistemu vsak predstavljal eno izmed koordinat. Simetralo kvadrantov razdelimo na izbrano število razredov in sredina razdelka je začetna sredina razreda. Na podlagi obeh parametrov nanesemo vse enote $v$ koordinatni sistem in jih pripišemo tisti sredini (skupini), od katere so evklidsko najmanj oddaljeni. Nove vrednosti znotraj posamezne skupine so osnova za izračun nove sredine razreda. In postopek ponovimo na podlagi novih sredin, ki ga nato ponavljamo toliko časa, dokler v neki ponovitvi vsaj 98 \% enot ne spremeni več pripadnosti skupini (slika 16) (ArcGIS, 2005). Končen rezultat je na začetku določeno število skupin, znotraj katerih so si enote glede na izbrane parametre kar najbolj podobne, skupine pa kar najbolj različne.

Pri nadzorovanih klasifikacijah skušamo enote uvrstiti v enega izmed znanih razredov, katere smo določili sami. Postopek poteka na osnovi učenja. Sami opredelimo učna območja, za katere vemo katera kategorija (tip prsti) se tam nahaja. Učna območja izdelamo na podlagi poznavanja pokrajine, letalskih ali digitalnih ortofoto posnetkov ali terenskega proučevanja. $\mathrm{Na}$ učnih enotah postopek "naučimo", kako se posamezni parametri vedejo in izdelamo podpise ali signature, ki vsebujejo multivariatne opisne statistike vseh parametrov za vsako kategorijo. Ostale enote nato uvrstimo v tisti razred, ki so mu najbolj podobne. Pri klasifikaciji največje verjetnosti (maximum likelihood) za vsak razred izračunamo verjetnost vsake enote 
(glede na izbrane parametre), da pripada temu razredu. Enoto (celico) pripišemo tistemu razredu, za katerega obstaja največja verjetnost pripadnosti.

\section{Slika 16: Postopek razvrščanja v skupine}

Picture 16: Cluster analysis algorithm

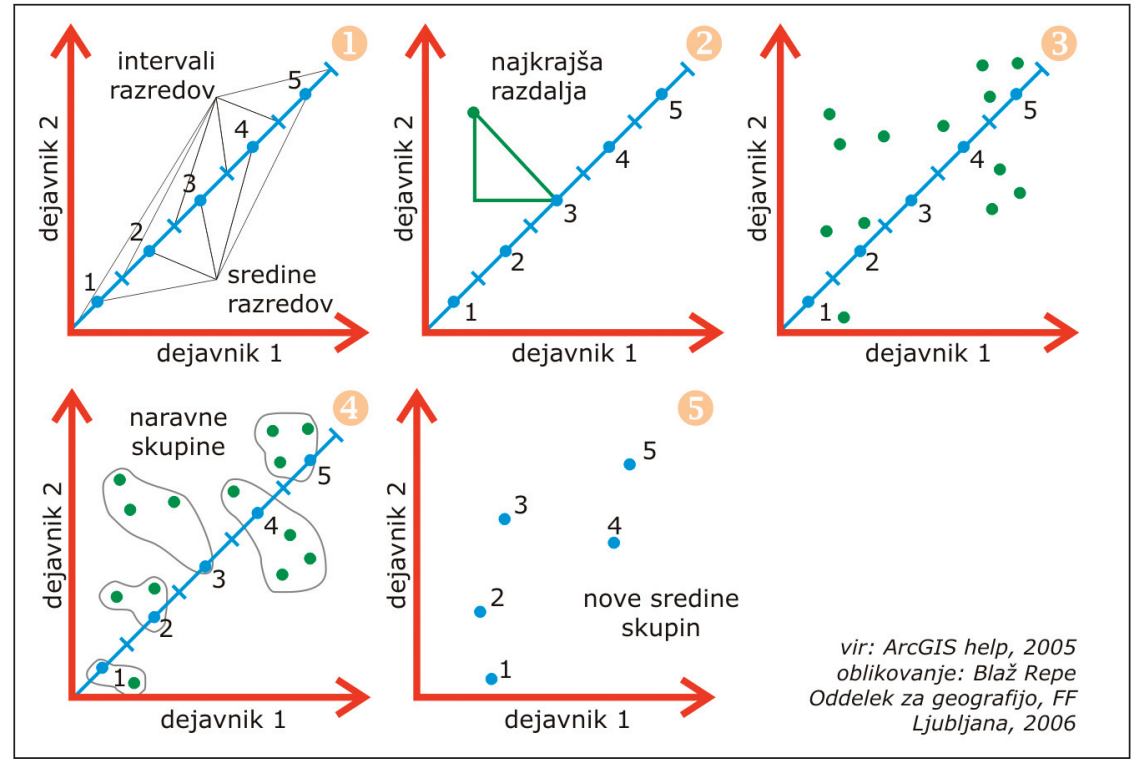

Vir: ArcGIS, 2005

Samo postopek se začne z določevanjem učnih območij. Za vsak pričakovan razred posebej določimo čim več, kar najbolj podobnih celic. Učna območja naj bodo tako po površini čim večja, in obenem homogena, kar je pogosto izključujoče. Na podlagi celic znotraj učnih območij, za vsak razred iz parametrov (dejavnikov) izračunamo multivariatne opisne statistike, ki se nato zapišejo v podpise ali signature. Postopek nato za vsako celico primerja parametre $\mathrm{z}$ opisanimi podpisi in celico uvrsti v najbolj ustrezen razred (tistega, za katerega obstaja največja verjetnost) (Ramšak, 2004 in Oštir, 2005).

Ugotavljanje tipov prsti na podlagi nadzorovane klasifikacije je še korak naprej. $\mathrm{Na}$ izbranih lokacijah proučimo lastnosti prsti in opravimo laboratorijske analize vzorcev. Za prsti v okolici izkopanega in opisanega profila smemo predpostaviti, da pripadajo istemu tipu, zato celice blizu lokacije predstavljajo dobro učno območje. Isti tip prst, na drugi lokaciji bo imel zelo verjetno podobne, če ne celo enake dejavnike, ki so pogojevali njegov nastanek. Več lokacij ko proučimo, lažje in bolje bomo naučili postopek klasifikacije in kvalitetnejši bo končni rezultat.

Tretji postopek je interpolacija, ki pomeni, da iz točkastih meritev napovedujemo merjene vrednosti za neznane lokacije znotraj območja proučevanja. Interpolacija je spreminjanje točkovnih informacije v zvezna površja. Za interpolacijo uporabljamo različne metode kot so 
površja trendov, regresijski modeli, Thiessen-ovi (Voronoi-jevi) poligoni najbližjih sosedov, linearne interpolacije (obratne razdalje) itd. Vse metode dajo zelo podobne rezultate, če je količina točkastih meritev velika. Pri manjšem številu pa je izbira metode interpolacije zelo pomembna, če želimo, da rezultati ne bodo zavajajoči. Z geostatistično metodo, ki jo poznamo tudi pod imenom kriging, želimo izvesti optimalni postopek interpolacije, katerih rezultat je gladko spreminjajoče se površje, ki ima nizke napake ocen na neznanih lokacijah. Matematično-statistično ozadje kriginga je dokaj zapleteno, vendar mnogo GIS programov omogoča tako imenovane "black box" analize, pri katerih samega postopka niti ni potrebno poznati, da pridemo do končnega rezultata. Takšne analize so na prvi pogled precej privlačne, saj se nam ni potrebno mučiti z zahtevnimi enačbami in funkcijami, vendar moramo biti zelo pazljivi pri uporabi in interpretaciji rezultatov (Burrough, in McDonnell, 1998).

Kriging temelji na predpostavki, da je prostorska variabilnost pojava, ki jo predstavljajo z vrednosti, statistično homogena na celotno površini. Uporaba kriginga je zato vprašljiva, če se proučevani pojav v prostoru razporeja izrazito nezvezno, s hitrimi spremembami, zato končni rezultat ne bo odražal realnega stanja. Prostorsko variabilnost kvantitativno opredelimo s semivariogramom (slika 17), ki ga ocenimo z vzorčnim semivariogramom. Vzorčni semivariogram izračunanamo na podlagi poznanih točkastih meritev. Njegova vrednost na vmesni razdalji h je povprečna kvadratna razlika z-vrednosti parov meritev, ki jih ločuje razdalja h ( $\mathrm{n}$ je število parov meritev, ki jih ločuje razdalja h):

$$
\hat{\gamma}(h)=\frac{1}{2 n} \sum_{i=1}^{n}\left\{z\left(x_{i}\right)-z\left(x_{i}+h\right)\right\}^{2}
$$

Slika 17: Semivariogram

Picture 17: Semivariogram

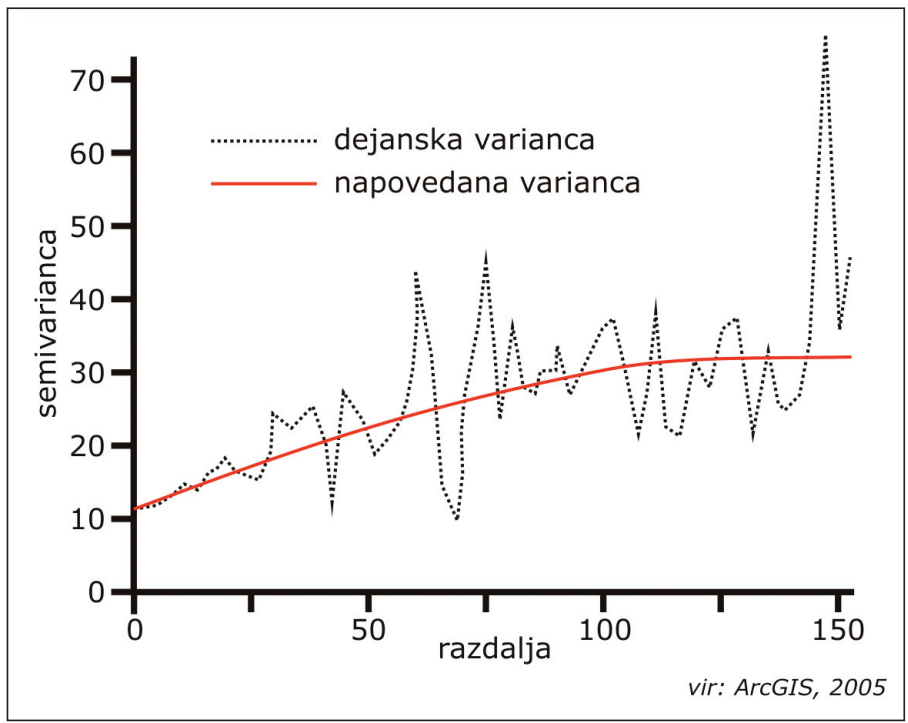


Iz slike je razvidno, da semivarianca narašča $\mathrm{z}$ oddaljenostjo med paroma meritev, vendar se na določeni oddaljenosti (range) spreminja še zelo malo. To pomeni, da variacija zvrednosti ni več v prostorski korelaciji. Ali drugače povedano, bolj ko so meritve blizu skupaj, manjša je variabilnost z-vrednosti in boljša je napoved. Razpon x osi je opredeljen z največjo razdaljo med dvema znanima meritvama. Kriging ponuja dve vrsti ocene površja: navaden (ordinary) in splošen (universal) kriging. Navaden kriging skuša prilagoditi semivariogram eni od matematičnih funkcij (sferična, krožna, eksponentna, gausova ali linearna). Pri splošnem krigingu predpostavimo, da je prostorska variabilnost z-vrednosti posledica uporabne, deterministične ali napovedljive variabilnosti, prostorsko avtokorelirane, težko razložljive variabilnosti in nekoreliranega šuma.

Prvi dve opisani metodi smo uporabili za preverjanje in obogatitev naših spoznanj o prostorskem razporejanju tipov prsti v krajinskemu parku Lahinja predvsem tam, kjer smo se drobne variabilnosti zavedali, vendar je nismo znali prikazati. Z metodo kriginga smo skušali izračunati in prikazati debelino odeje prsti.

\section{Slika 18: Rezultat razvrščanja v skupine}

Picture 18: Cluster analysis results

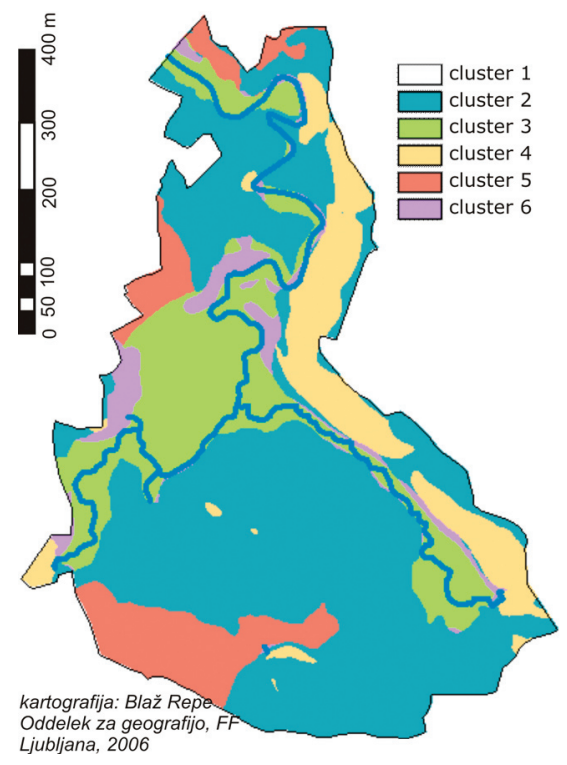

Nenadzorovana klasifikacija oziroma cluster analiza naravnih dejavnikov (matične podlage, reliefa, voda in pokrovnosti) je potrdila naše ugotovitve. Rezultat je $1+5$ kombinacij (prva predstavlja okolico, za katero nimamo podatkov), ki jih zlahka preimenujemo v tipe prsti (slika 17): cluster 2 - rjave pokarbonatne prsti in izprane prsti, cluster 3 - obrečne prsti, cluster 4 - rjave pokarbonatne prsti, cluster 5 - izprane prsti in cluster 6 - koluvialne prsti. 
Prepoznani tipi se v precej dobro ujemajo z našimi terenskimi predpostavkami. Razlike se pojavijo tam, kjer so digitalni, vhodni podatki premalo natančni. Klasifikacija ni izločila obeh zamočvirjenih območij Lug, kjer se pojavljajo oglejene prsti ter zaplate rendzin, ki so nastale na opuščenem peskokopu in so povsem antropogenega nastanka. Samo razvrščanje v skupine pa ni rešilo osnovne zadrege ločevanja različnih tipov rjavih pokarbonatnih in izpranih prsti v osrednjem, ravninskem delu parka.

Slika 19: Rezultat uvrščanja v skupine

Picture 19: Maximum likelihood classification results

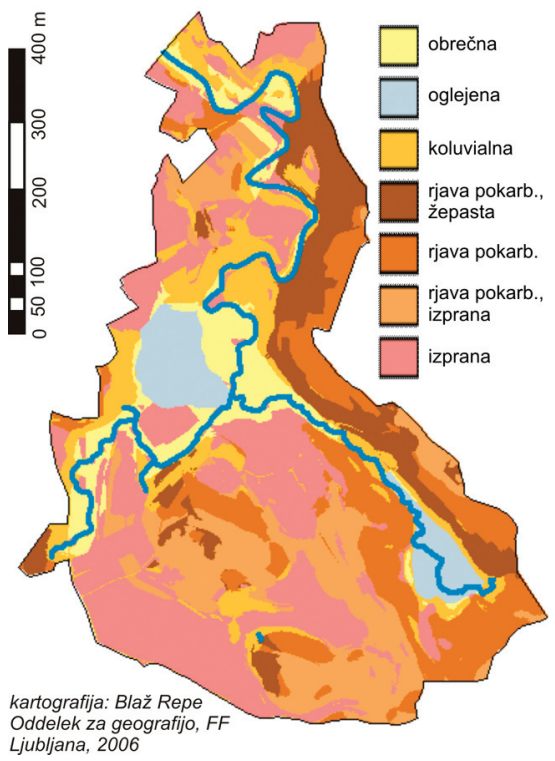

Veliko bolj natančna in uspešna se je izkazala nadzorovana klasifikacija ali uvrščanje v skupine. V postopku smo najprej izdelali 30 učnih območij, za katere smo natančno poznali tip prsti (vsak tip prsti so zastopala vsaj tri učna območja na različnih delih parka). Okolico izkopa in opisa profila smo razširili na bližnjo okolico toliko, kolikor so nam dopuščali dejavniki. Znotraj učnega območja so zgoraj omenjeni dejavniki ostali homogeni in so odražali dejavnike, ki so značilni za samo točkasto lokacijo. Na podlagi učnih območij smo izdelali podpise ali signature za sedem prepoznanih tipov prsti. Analiza dejavnikov znotraj signatur je pokazala, da ima največji vpliv na razvoj in razporeditev prsti naklon pobočja, ki mu sledi matična podlaga in nazadnje nadmorska višina (slika 19). Pestrost nekaterih naravnih dejavnikov, predvsem drobno, a hitro menjavanje naklona pobočij je pokazala, da so prsti še mnogo bolj pestre kot smo pričakovali. Na pestrost smo opozarjali že ob terenskem proučevanju, ki je nismo mogli zajeti v kartografski prikaz (slika 18). 
Slika 20: Odločilni pedogenetski dejavniki za razmestitev tipov prsti v krajinskem parku Lahinja Picture 20: Factors of soil distribution in the Lahinja landscape park

Signature Comparison Chart

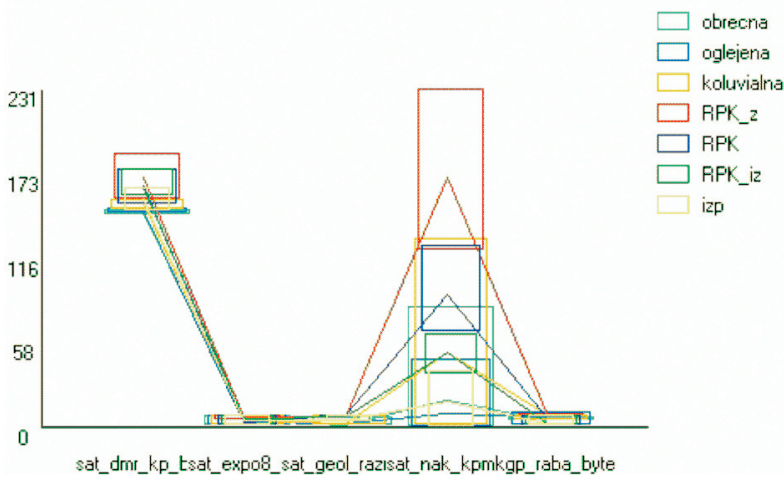

Slika 21: Debelina odeje prsti v krajinskem parku Lahinja

Picture 21: Soil depth in the Lahinja landscape park

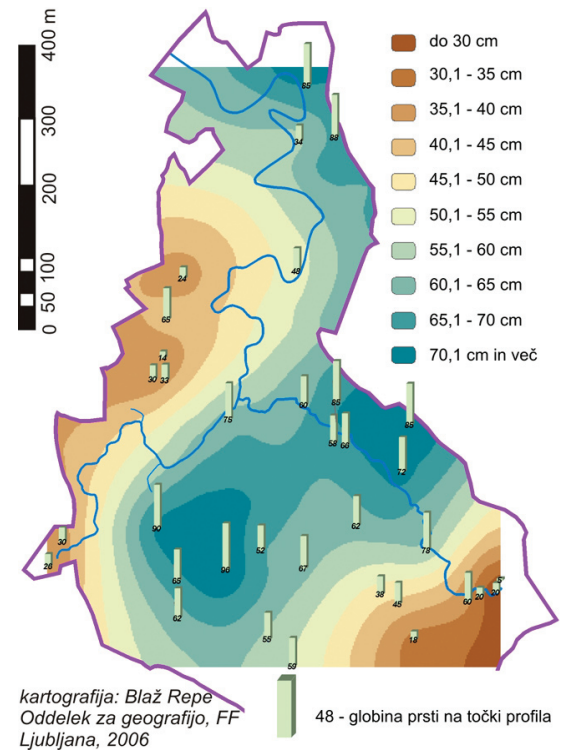

Za konec smo želeli prikazati tudi, kako se v krajinskem parku spreminja debelina odeje prsti. Postopek kriginga smo izvedli na podlagi terenskih meritev globine pojavljanja matične podlage oziroma talne vode iz katerih smo najprej izračunali vzorčni semivariogram. Ta je pokazal največjo podobnost s funkcijo kroga, zato smo uporabili navadni kriging, s krožnim 
semivariogramom. Tudi ta rezultat je precej pričakovan (slika 20) in v skladu s prejšnjima dvema, ki nakazuje, da je tudi pri debelini prsti odločilno vlogo odigral prav naklon pobočij. Največje debeline se pojavljajo v osrednjem ravninskem delu parka ter na zakraseli uravnavi, s katero se zaključi vzhodno obrobje. Najplitvejše prsti so na strmejšem južnem in zahodnem obrobju, ter v Lugah, kjer debelino omejuje talna voda, ki se pojavlja komaj $10 \mathrm{~cm}$ pod površjem.

\section{ZAKLJUČEK}

Geografi proučujemo prsti kot sestavni del pokrajine že vrsto let. Pristop, ki se je uveljavil v slovenski geografiji je izrazito genetski in se v marsičem razlikuje od pedološkega pristopa, saj nas na prvem mestu zanimajo povezave med prstjo in ostalimi naravnimi dejavniki. Pedogeografija je ena od temeljnih vej fizične geografije, enakovredna ostalim (Vrišer, 2002), zato nas preseneča, da se razen redkih izjem malo geografov odloči za proučevanje prsti, še posebej pri regionalnogeografskih raziskavah ali delih. Premalo pedogeografskih vsebin je tudi pri diplomskih delih študentov. Glavni krivec je na ljubljanskem Oddelku za geografijo je vsekakor študijski program, ki v višjih letnikih, predvsem pri usmeritvah ne omogoča poglobljenega proučevanja prsti. Upamo, da se boljši časi obetajo z uveljavitvijo študija po bolonjskem načinu, ki predvideva tudi možnost usmeritve $\mathrm{v}$ aplikativno fizično geografijo, kjer bo prostor tudi za proučevanje prsti.

Geografski način proučevanja prsti v pokrajini je znan sedaj že vrsto let. Na začetku smo bili močno odvisni od pedoloških metod, v zadnjih dveh desetletjih smo začeli uporabljati lastne, pedogeografiji prilagojene metode. Poudarek na terenskem proučevanju, poenostavitev laboratorijskih metod, ki so predstavljeni $\mathrm{v}$ treh metodoloških priročnikih, skupaj z visokošolskimi učbeniki omogočajo razumevanje prsti vsakomur, ki ga ta tematika privlači. Obenem smo geografi tudi edini, ki na osnovnošolskem in srednješolskem nivoju skrbimo za izobraževanje o prsteh ter edini na visokošolskem nivoju, ki nas zanimajo prsti tudi izven meja naše države.

Vsem izobraževanjem in priročnikom navkljub, pa učitelji še vedno smatrajo, da je obravnavanje prsti $\mathrm{v}$ osnovnih in predvsem srednjih šolah zahtevno. Očitno razlaga prsti in njihova razprostranjenost na podlagi pedogenetskih dejavnikov res ni preprosta, saj smo ugotovili, da se geografi ne lotevamo avtorskega prikaza prsti v pokrajini, torej karte. Izdelava prostorskega prikaza na podlagi točkastih meritev je pogosto zapleteno opravilo, pri čemer nam množica pedogenetskih dejavnikov in njihovo součinkovanje vsekakor ni v pomoč. Lastne izkušnje kažejo, da to znanje vendarle imamo. Čemu ga ne uporabimo ali nočemo uporabljati, pa smemo morebiti povezati tudi z nizko stopnjo samozavesti, češ da znajo druge, ožje usmerjene in specializirane stroke bolje. Induktivni in sintezni način razmišljanja, ki ga gojimo znotraj geografskih strok, bi nam ravno v pedogeografiji prišel še kako prav.

Opisan primer proučevanja prsti v krajinskem parku Lahinja nam odpravlja te zadržke. Vsak geograf je sposoben sam izpeljati katerikoli opisano fazo pedogeografskega raziskovanja, kar kaže tudi pregled pedogeografske literature. Uporaba res preprostih geoinformacijskih orodij pa nam omogoča, da ne omagamo na sami ciljni črti. Pregled literature in izbor ustreznih 
digitalnih podatkov omogoča izpeljavo nenadzorovanih klasifikacij dejavnikov oziroma razvrščanja v skupine. Rezultati, ki jih dobimo so zelo podobni našim vtisom na terenu. Predvsem pa manj izkušenim s področja proučevanja prsti omogočajo sintezo, za katero sami neupravičeno smatrajo, da je niso sposobni izpeljati. Rezultati razvrščanja dejavnikov nam bistveno olajšajo terensko delo, ga usmerjajo, zmanjšajo število lokacij proučevanja in preprečujejo podvajanje meritev. Terenska proučevanja in/ali rezultati laboratorijskih analiz pa so podlaga za natančno nadaljnje delo, to so nadzorovane klasifikacije dejavnikov ali uvrščanje v znane, na terenu ugotovljene tipe prsti. Končen rezultat je močno odvisen od kvalitete podatkov. Boljši in natančnejši bodo, bolj verodostojni bodo naši rezultati, končen prikaz in tudi razlaga pokrajine.

Prikazali smo tudi primer interpolacije točkastih meritev na celoten proučevani del pokrajine. Interpolacija je še posebej primerna pri tehničnih klasifikacijskih sistemih prsti, kjer so tipi prsti opredeljeni s kvantitativnimi parametri. Na podlagi kombiniranja (prekrivanja) parametrov različnih interpoliranih površij (globina, reakcija, delež organskih snovi ali posameznih mineralnih komponent, vsebnost vode itd.), lahko izločimo posamezne tipe prsti. Slovenska klasifikacija prsti je izrazito genetska, zato sta metodi razvrščanja in uvrščanja izrazito primernejši. Interpolacija nam služi za prikaz spreminjanja posameznega parametra v prostoru.

Marsikateri geograf se ustraši tudi ob besedah geografski informacijski sistemi in kvantitativne oziroma statistične metode. Misel na množico zapletenih enačb, matematičnih funkcij ter GIS orodij ni preveč privlačna. Na srečo pa precej tudi zelo zapletenih analiz (npr. kriging) poteka po "black box" principu, kjer samega postopka ne spoznamo v celoti, ampak le princip. Nekaj osnov je vsekakor potrebno poznati, predvsem za pravilno interpretacijo ter vrednotenje dobljenih rezultatov.

Po toliko letih proučevanja prsti in množici opravljenega dela pedogeografije ne moremo več smatrati za mlado vejo geografije, čeprav bomo v primerjavi z ostalimi vedno kakšen korak ali desetletje zadaj. Narava in odlični učitelji so nam pripravili izvrstno podlago, ki bi morali bolje izkoristiti ter vzpostaviti sodelovanje z ostalimi strokami ali jim končno celo postati konkurenčni.

\section{Viri in literatura}

ArcGIS, 2005. Datoteka za pomoč pri uporabi programskega paketa ArcGIS 9.1 (Help).

Belec, B., 1968. Osnove fizične geografije. Pedagoška akademija. Maribor. 353 str.

Bridges, E.M., Davidson, D.A., 1982. Principles and Applications of Soil Geography. Longman, London/New York. 297 str.

Burrough, P.A., McDonnell, R.A., 1998. Principles of Geographical Information Systems. Oxford University Press. New York. 333 str.

Campbell, J.B., 2002.Introduction to Remote Sensing (2nd edition). Taylor \& Francis, London.

COBISS/OPAC V4.2: http://www.izum.si/scripts/cobiss?ukaz=getid\&lang=win\&lani=si (citirano: 11.3.2006). 
Deckers, J.A., Nachtergaele F.O., Spaargaren, O.C. (ur.), 1998: World Reference Base For Soil Resources - Introduction. Publishing Company Acco. Leuve.

Digitalna pedološka karta 1:25.000, 2005. Občina Ivančna Gorica (izrez). Talni informacijski sistem, Center za pedologijo in varstvo okolja Biotehniška fakulteta, Ljubljana.

Digitalni ortofoto posnetki, 1:5.000, 2005. Geodetska uprava republike Slovenije.

Driessen, P., Deckers, J.A., Nachtergaele, Spaargaren, O.C. (ur.), 2001: Lecture Notes On The Major Soils Of The World. Food And Agriculture Organization Of The United Nations. Rome.

Ferder, T., 1994. Regionalna geografija Zgornje savinjske doline s poudarkom na rastju in prsti. Diplomsko delo. Oddelek za geografijo, Filozofska fakulteta, Univerza v Ljubljani. Ljubljana.

Hemijske metode ispitivanja zemljišta, 1966. Priručnik za ispitivanje zemljišta. Knjiga I. Jugoslovensko društvo za proučavanje zemljišta. Beograd. 270 str.

Hidropedološka in agromeliroacijska ekspertiza proizvodnjega območja Dragatuš, Veliki in Mali Nerajec, Belčji vrh in Mala Lahinja v občini Črnomelj, 1986. Inštitut za hmeljarstvo in pivovarstvo Žalec.

Ilešič, S., 1960. Geografija prsti in rastja (skripta za geografe). Naravoslovna fakulteta v Ljubljani, Univerzitetna založba. Ljubljana.

Klemen, J., 1996. Regionalna geografija Babnega polja: s poudarkom na prsteh in rastju. Diplomsko delo. Oddelek za geografijo, Filozofska fakulteta, Univerza v Ljubljani. Ljubljana.

Kocjančič, D., Germek, V., Rednak, M., Cunder, T., Lukačič, M., 1987. Tehnična navodila za izdelavo agrokarte (ocenjevanje rabe in produktivnosti kmetijskih zemljišč). Republiški komite za kmetijstvo, gozdarstvo in prehrano in Zveza kmetijskih zemljiških skupnosti Slovenije. Ljubljana. 59 str.

Komac, B., Zorn, M., 2005a. Soil erosion on agricultural land in Slovenia - measurements of rill erosion in the Besnica valley = Erozija prsti na kmetijskih zemljiščih v Sloveniji - meritve žlebične erozije v dolini Besnice. Acta geographica Slovenica, Letnik 45, št. 1 (2005), str. 53-86. Geografski inštitut Antona Melika ZRCSAZ. Ljubljana.

Komac, B., Zorn, M., 2005b. Erozija prsti na kmetijskih zemljiščih v Sloveniji Ujma, Št. 19 (2005), str. 163-174. Ljubljana

Lillesand, T.M., Kiefer, R.W., 1994. Remote Sensing and Image Interpretation (3rd edition). John Wiley \& Sons, Inc. Canda. 750 str.

Lovrenčak, F., 1974. Nekatere nove smeri v pedogeografiji in fitogeografiji. Geografski vestnik, letnik 46, 1974, str. 87-96. Zveza geografskih društev Slovenije. Ljubljana.

Lovrenčak, F., 1976. Nova klasifikacija prsti (nekaj novosti iz pedogeografije). Geografski vestnik, letnik 48, 1976, str. 181-190. Zveza geografskih društev Slovenije. Ljubljana.

Lovrenčak, F., Plut, D., Gams, I., 1978a. Naravno-geografska analiza Kamna. Zgornje Posočje, zbornik 10. zborovanja slovenskih geografov. Geografsko društvo Slovenije. Ljubljana. Str. 275-290.

Lovrenčak, F., Plut, D., 1978b. Prirodne in družbeno-geografske značilnosti Breginja in okolice. Zgornje Posočje, zbornik 10. zborovanja slovenskih geografov. Geografsko društvo Slovenije. Ljubljana. Str. 291-312. 
Lovrenčak, F., 1979. Laboratorijske analize prsti (laboratorijski priročnik za geografe). PZE za geografijo, Filozofska fakulteta, Univerza Edvarda Kardelja v Ljubljani. Ljubljana.

Lovrenčak, F., 1981a. Pedogeografske značilnosti Šentjernejskega vršaja. Geografski vestnik, letnik 53 (1981). Zveza geografskih društev Slovenije. Ljubljana. Str. 17-30.

Lovrenčak, F., 1981b. Pedo in vegetacijsko-geografske značilnosti Gorenjske. Gorenjska, referati in gradivo na 12. zborovanju slovenskih geografov. Geografsko društvo Slovenije. Ljubljana. Str. 120-129.

Lovrenčak, F., 1984. Pedogeografske in vegetacijskogeografske značilnosti Dolenjske. Dolenjska in Bela krajina, prispevki za 13. zborovanje slovenskih geografov. Geografsko društvo Slovenije, Ljubljana. Str. 146-166.

Lovrenčak, F., 1987. Pedogeografske in vegetacijskogeografske značilnosti Notranjske.

Notranjska, zbornik 14. zborovanja slovenskih geografov. Zveza geografskih društev Slovenije. Postojna. Str. 179-192.

Lovrenčak, F., 1990. Pedogeografske in vegetacijskogeografske razmere v Koprskem Primorju. Primorje, zbornik 15. zborovanja slovenskih geografov. Zveza geografskih društev Slovenije. Ljubljana. Str. 53-59.

Lovrenčak, F., 1991. Pedogeografska regionalizacija Pomurske ravnine. Geografska problematika Severovzhodne Slovenije. Dela, št. 8. Oddelek za geografijo, Filozofska fakulteta, Univerza v Ljubljani. Ljubljana.

Lovrenčak, F., 1994. Pedogeografija. Oddelek za geografijo, Filozofska fakulteta, Univerza v Ljubljani. Ljubljana.

Lovrenčak, F., 1996. Pedogeografska regionalizacija Spodnjega Podravja s Prlekijo. Spodnje

Podravje s Prlekijo Str. Zbornik 17. zborovanja slovenskih geografov, Ptuj. Oddelek za geografijo, Filozofska fakulteta, Univerza v Ljubljani. 37-42

Lovrenčak, F., 1998a. Prsti (kartografsko gradivo). Geografski atlas Slovenije (Fridl, ur.). DZS, Ljubljana.

Lovrenčak, F., 1998b. Pedogeografske značilnosti. Geografija Slovenije (Gams in Vrišer ur.). Slovenska matica. Ljubljani.

Lovrenčak, F., 1999. Pedogeografske in vegetacijskogeografske značilnosti Julijskih Alp. Sonaravni razvoj v slovenskih Alpah in sosedstvu/1. Melikovi geografski dnevi. Dela, št. 13. Oddelek za geografijo, Filozofska fakulteta, Univerza v Ljubljani. Ljubljana.

Lovrenčak, F., 2002. Povezave med prstjo in rastlinstvom na vršajih v Planici. Geografski vestnik, letnik 74-1, 2002. Zveza geografskih društev Slovenije. Ljubljana. Str. 57-63

McCoy, R.M., 2005. Field Methods in Remote Sensing. The Guilford Press. New York, London. 159 str.

Merzlak, M., 1998. Geografija Pomežja s poudarkom na prsteh in rastlinstvu.

Metodika terenskog ispitivanja zemljišta i izrada pedoloških karata. Priručnik za ispitivanje zemljišta, knjiga IV. Beograd 1967.

Naša rodna zemlja. Okolje v Sloveniji, III. Raziskovanje tal, mladinska raziskovalna akcija.

Prirodoslovno društvo Slovenije. Ljubljana. 23 str.

Osnovna geološka karta SFRJ, list Črnomelj 1:100.000, 1972.

Oštir, K., 2005. Daljinsko zaznavanje (skripta). Fakulteta za gradbeništvo in geodezijo, Univerza v Ljubljani. 198 str. 
Pekolj, S., 1994. Zahodni del Posavskega hribovja s poudarkom na prsti in rastju. Diplomsko delo. Oddelek za geografijo, Filozofska fakulteta, Univerza v Ljubljani. Ljubljana.

Perko, D., Orožen Adamič, M., 1998. Slovenija: Pokrajine in ljudje. Mladinska knjiga. Ljubljana.

Petauer, M., 1999. Terenske in laboratorijske metode preučevanja prsti. Interno gradivo. Celje. Petauer, M., 2005. Preučevanje prsti kot pokrajinotvornega dejavnika v Celjski kotlini: (aplikacija za šolsko rabo). Magistrsko delo. Oddelek za geografijo, Filozofska fakulteta, Univerza v Ljubljani. Ljubljana.

Petrevčič, M., 1994. Geografija Kranjskega polja z obrobjem s poudarkom na prsti in rastju. Diplomsko delo. Oddelek za geografijo, Filozofska fakulteta, Univerza v Ljubljani. Ljubljana.

Podgoršek-Golob, T., 1995. Regionalna geografija občine Slovenj Gradec s poudarkom na prsti in rastju. Diplomsko delo. Oddelek za geografijo, Filozofska fakulteta, Univerza v Ljubljani. Ljubljana.

Pokrovnost in raba tal MKGP, 2002. Ministrstvo za kmetijstvo, Ljubljana.

Prus, T., 2000: Tipi tal v Sloveniji. Interno gradivo za študente. Center za pedologijo in varstvo okolja, Biotehniška fakulteta. Ljubljana.

Radinja, D., 1967. Morfogenetske poteze Goriškega polja. Geografski vestnik, Letnik. 39 (1967), str. 21-74. Zveza geografskih društev Slovenije. Ljubljana.

Radinja, D., 1969. Renške Dobrave - pokrajinski stik med fluvialno akumulacijo Soče in periglacialno akumulacijo Vipave. Letnik. 41 (1969), str. 61-74. Zveza geografskih društev Slovenije. Ljubljana.

Radišek Kuhar, S., 1992. Regionalna geografija občine Žalec s poudarkom na prsti in rastju. Diplomsko delo. Oddelek za geografijo, Filozofska fakulteta, Univerza v Ljubljani. Ljubljana.

Ramšak, I., 1993. Regionalna geografija velenjske kotline s poudarkom na prsti in rastju. Diplomsko delo. Oddelek za geografijo, Filozofska fakulteta, Univerza v Ljubljani. Ljubljana.

Ramšak, Ž., 2004. Vrednotenje pokrajinskoekoloških tipov Slovenije v luči pokrovnosti izdelane s klasifikacijo satelitskih posnetkov Landsat. Diplomsko delo. Oddelek za geografijo, Filozofska fakulteta, Univerza v Ljubljani. Ljubljana. 102 str.

Repe, B., 2000. Študijsko gradivo pri predmetu vaje iz pedogeografije. Spletno študijsko gradivo: http:/www.ff.uni-lj.si/oddelki/geo/gradiva/studijska_gradiva/pedogeografija/ gradiva_pedogeografija.html (citirano: 3.3.2006).

Repe, B., 2001. Terenske in laboratorijske metode proučevanja prsti. Oddelek za geografijo, Filozofska fakulteta, Univerza v Ljubljani. Ljubljana.

Repe, B., 2002. Degradacija prsti v Sloveniji. Magistrsko delo. Oddelek za geografijo, Filozofska fakulteta, Univerza v Ljubljani. Ljubljana.

Repe, 2004 - Soils of Slovenia. Slovenia - A geographical overview. Zveza geografskih društev Slovenije. Založba ZRC, Ljubljana.

Repe, B., 2005a. Uporabnost nove svetovne klasifikacije prsti (FAO WBR) v šolski geografiji. Naravne nesreče/14. Ilešičevi dnevi, 22.-24. september 2005. Oddelek za geografijo, Filozofska fakulteta, Univerza v Ljubljani. Ljubljana 
Repe, B., 2005b. Nizi svetovne WRB klasifikacije prsti v geografskih učbenikih. Geografija v šoli, let. 15, št. 3, 2005. Zavod republike Slovenije za šolstvo. Ljubljana

Repe, B., 2006. Svetovna WRB klasifikacija prsti. Geografski obzornik, let. 53, št. 1.

Rupreht, J., Šporar, M., Zupan, M., Stepančič, D., Vidic, J.N., Lobnik, F., Vrščaj, B., Prus, T., Tič, I., 1994. Pedološka karta Slovenije 1:25000 (kartografsko gradivo). Center za pedologijo in varstvo okolja, Biotehniška fakulteta, Univerza v Ljubljani.

Slapernik, T., 1994. Geografske značilnosti Spodnje Vipavske doline in Goriškega polja: s poudarkom na prsti in rastju. Diplomsko delo. Oddelek za geografijo, Filozofska fakulteta, Univerza v Ljubljani. Ljubljana.

Soil Survey Division Staff. 1993. Soil survey manual. Soil Conservation Service. U.S. Department of Agriculture Handbook 18. http://soils.usda.gov/technical/manual/ (citirano: 28.3.2006).

Spletni katalog seminarskih nalog Oddelka za geografijo: http:/www.ff.uni-lj.si/oddelki/geo/ oddelek/knjiznica/seminarske_naloge/seminarske_naloge.html (citirano: 11.3.2006).

Stepančič, D., Lobnik, F., Prus, T., Kalan, J., Vidic, J.N., Kajfež-Bogataj, L., Zupančič, M., Seliškar, A., Stritar, A., Šrok, D., 1986. Osnovna pedološka karta SFRJ, 1:50.000 (Ljubljana, Ptuj, Murska Sobota) s komentarji. Geodetski zavod Slovenije, Biotehniška fakulteta, Agronomija, Katedra za pedologijo, prehrano rastlin in ekologijo. Ljubljana

Stritar, A., 1965. Značilna zaporedja talnih oblik v Sloveniji. Geografski obzornik, letnik 12, št. 3. Ljubljana.

Stritar, A., 1990: Krajina, krajinski sistemi. Raba in varstvo tal v Sloveniji. Partizanska knjiga, Ljubljana.

Sušin, J., 1983. Kmetijski tehniški slovar (gradivo za pedološki slovar). Nauk o tleh (1. knjiga, 1. zvezek). VTOZD za agronomijo, Biotehniška fakulteta, Univerza Edvarda Kardelja v Ljubljani. 36 str.

Tan, K.H., 2005. Soil Sampling, Preparation and Analysis (second edition). Taylor\&Francis Group, Boca Raton. 623 str.

Temeljni topografski načrt 1:5.000, 2004. Listi: G1907, G1908, G2047, G2048. Geodetska uprava republike Slovenije, Ljubljana.

Tumač za list Črnomelj, L33-91, osnovna geološka karta SFRJ 1:100.000, Geološki zavod Ljubljana, Geološki zavod Zagreb, 1984.

Stritar, A., 1990: Krajina, krajinski sistemi. Raba in varstvo tal v Sloveniji. Partizanska knjiga, Ljubljana.

URBSOIL, 2005. Spletna stran: http://www.urbsoil.bf.uni-lj.si/nivo/2_urbsoil_v_lj/urbsoil_ lj.htm (citirano, 25.3.2006)

Uršič, A., 2001. Regionalna geografija Sorškega polja: poudarek na prsteh in rastlinstvu. Diplomsko delo. Oddelek za geografijo, Filozofska fakulteta, Univerza v Ljubljani. Ljubljana.

Vovk Korže, A., 1992. Vpliv reliefa na lastnosti prsti med Bočem in Dravinjskimi goricami. Magistrska naloga. Oddelek za geografijo, Filozofska fakulteta, Univerza v Ljubljani. Ljubljana.

Vovk Korže, A., 1995. Pokrajinsko ekološke enote severovzhodne Slovenije. Doktorska disertacija. Oddelek za geografijo, Filozofska fakulteta, Univerza v Ljubljani. Ljubljana. 
Vovk Korže, A., 1997. Ekološko vrednotenje prsti v Dravinjskih goricah in dolini Dravinje. Geografski vestnik, letnik 69, 1997. Zveza geografskih društev Slovenije. Ljubljana. Str. 11-30.

Vovk Korže, A., Lovrenčak F., 2001. Priročnik za laboratorijske analize prsti v geografiji. Oddelek za geografijo, Filozofska fakulteta, Univerza v Ljubljani in Oddelek za geografijo, Pedagoška fakulteta v Mariboru. Ljubljana, Maribor.

Vovk Korže, A., 2003a. Novejši trendi v geografskem raziskovanju prsti in rastlinstva v Sloveniji in v tujini. Dela 20. Geografija pred novimi izzivi (Znanstveni simpozij ob 80letnici akademika prof. dr. Ivana Gamsa). Oddelek za geografijo, Filozofska fakulteta. Ljubljana.

Vovk Korže, A., 2003b. Položaj in vsebinska usmerjenost fizične geografije v Sloveniji in tujini. Geografski vestnik, letnik 75-1, 2003. Zveza geografskih društev Slovenije. Ljubljana. Str. 95-102.

Vovk Korže, A., 2003c: Nov pristop k poznavanju prsti. Geografija v šoli, letnik XII, št. 2. Zavod republike za šolstvo. Ljubljana.

Vovk Korže, A., Lovrenčak F., 2004. Priročnik za spoznavanje prsti na terenu. Oddelek za geografijo, Filozofska fakulteta, Univerza v Ljubljani. Ljubljana.

Vrišer, I., 1953. Erozija prsti. Proteus, Letnik 16, št. 3 (november), str. 100-105.

Vrišer, I., 2002. Uvod v geografijo (7. natis). Oddelek za geografijo, Filozofska fakulteta, Univerza v Ljubljani. Ljubljana. 414 str.

Zupan, M., 2000: Raziskave onesnaženosti tal s predlogom programa ukrepov nujnih sanacij (Koncept izvajanja monitoringa onesnaženosti tal RS in poročilo za leto 1999). Center za pedologijo in varstvo okolja. Biotehniška fakulteta. Ljubljana.

Zupan, M., Grčman, H., Prus, T., Hodnik, A., Vrščaj, B., 2001. Določanje fizikalnih in kemijskih lastnosti tal. Spletno gradivo (http://www.bf.uni-lj.si/cpvo/; citirano: 14.1.2004). Center za pedologijo in varstvo okolja. Biotehniška fakulteta. Ljubljana.

Žvan-Hrvatin, M., 1996. Geografija dobrepoljskega krasa s poudarkom na prsteh in rastju (poskus pokrajinsko-ekološke členitve). Diplomsko delo. Oddelek za geografijo, Filozofska fakulteta, Univerza v Ljubljani. Ljubljana.

\section{NEW APPROACHES IN SLOVENIAN SOIL GEOGRAPHY}

\section{Summary}

Slovene soil geography has an equal position within geographical science system, but physical- and regional geographical researches do not indicate that at all. There are also very few geographers who research soils and neglecting of this research was pointed out by Ilešič already in 1960. Geographical soil research evolved from pedology, but common language was not restored and both branches of science further developed without notable cooperation. Geographers have incorporated pedological methodology and their system of classification. In result soil geography is considered underdeveloped for many years; also the knowledge about soils is often too broad and is rarely joined into integrity. Links to other landscape elements can not easily be found and the practical usage of gained knowledge is even rarer. 
Today we can hardly say that soil geography is still a young branch of science. Over half of the century of expert, scientific and pedagogical activity, three university textbooks, three methodological manuals show high level of activity. Geographers are also the only ones who take care of primary and secondary school education on soils, but there is still a lot work to be done on the university level. Deep in thought and intensive pre graduation studies will bring up more interest in soil research within entire geography and also in post graduation thesis. Further explorations are expected the field of terminology, where together with pedology we are lagging behind world research. Nearly totally blank is also the territory of geographical soil cartography. Thematic cartography belongs to one of the most important forms of presentations of geographical research results.

If our goal is efficient soil research and also their presentation of the extent in a given landscape, clear purposes and aims should be defined. Only in this way necessary sources and available literature can be collected. Through that we can corroborate theoretical knowledge about soil forming factors and processes which are to be studied in the field. Soil field survey is still the foundation of soil research where we explore the interaction between factors, processes and soils. Field measurements are the starting point for sampling and further laboratory analysis. With all this data and cognitions we can create a true landscape picture about soils and mutual interactions with parent material, climate, topology, waters and living world.

Numerous factors and processes make geographical soil research quite demanding, explanation of relative position laborious and presentation difficult. The use of some GIS tools (supervised and unsupervised classification of remotely sensed images) and quantitative, spatial statistic methods (interpolation - kriging) ease the synthesis and cartographic work also to non soil science experts. Good quality of digital data and their modeling rationalizes soil field survey, produces non expensive soil maps and explanation of links between soils and other physical elements of the landscape. 